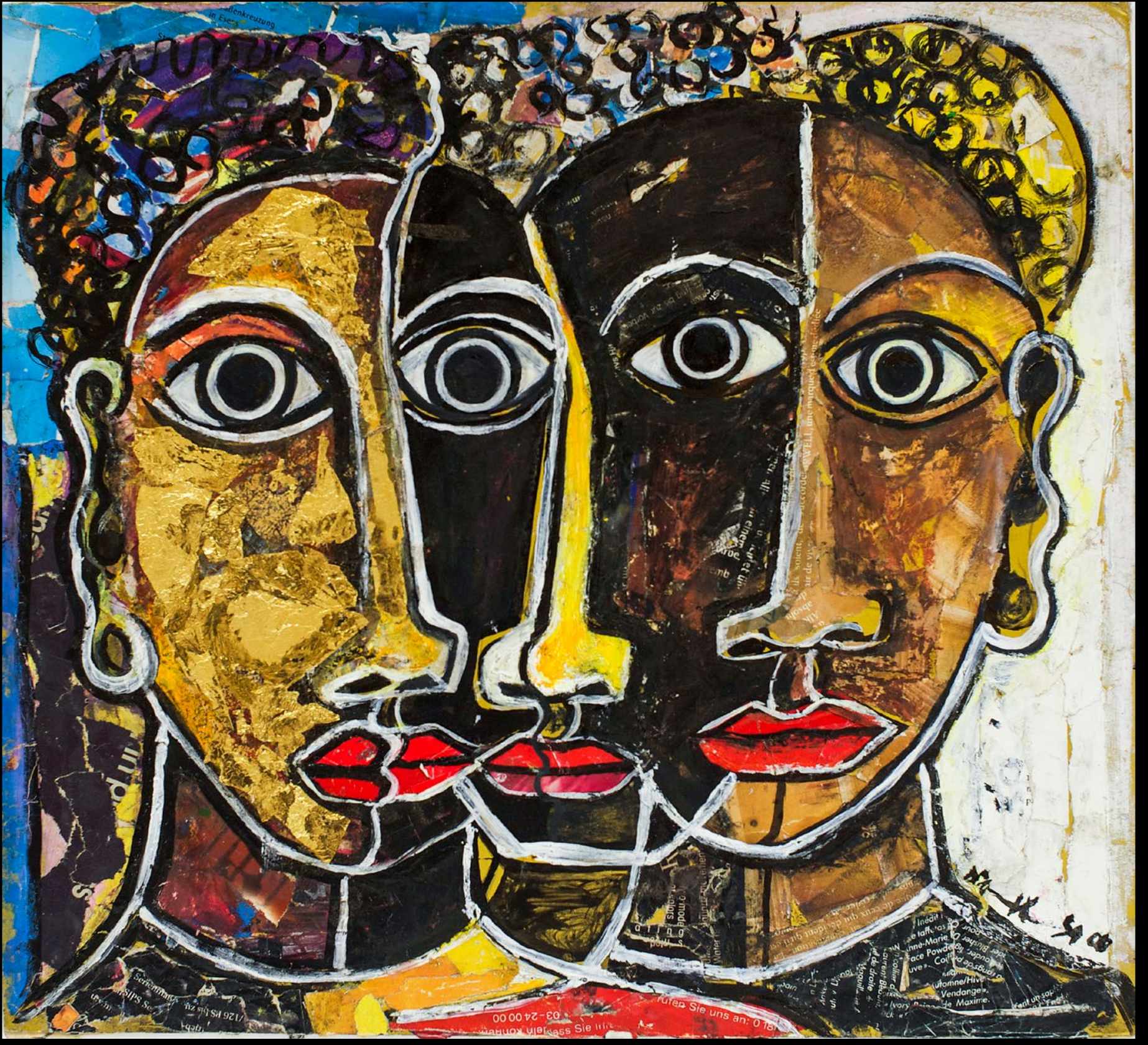

NCLUSION MATIERS The Foundation for Shared Prosperity

OVERVIEW 
(C) 2013 International Bank for Reconstruction and Development / The World Bank 1818 H Street NW, Washington DC 20433

Telephone: 202-473-1000; Internet: www.worldbank.org

Some rights reserved

This work is a product of the staff of The World Bank with external contributions. Note that The World Bank does not necessarily own each component of the content included in the work. The World Bank therefore does not warrant that the use of the content contained in the work will not infringe on the rights of third parties. The risk of claims resulting from such infringement rests solely with you.

The findings, interpretations, and conclusions expressed in this work do not necessarily reflect the views of The World Bank, its Board of Executive Directors, or the governments they represent. The World Bank does not guarantee the accuracy of the data included in this work. The boundaries, colors, denominations, and other information shown on any map in this work do not imply any judgment on the part of The World Bank concerning the legal status of any territory or the endorsement or acceptance of such boundaries.

Nothing herein shall constitute or be considered to be a limitation upon or waiver of the privileges and immunities of The World Bank, all of which are specifically reserved.

\section{Rights and Permissions}

\section{(c) ()}

This work is available under the Creative Commons Attribution 3.0 Unported license (CC BY 3.0) http://creativecommons.org/licenses/by/3.0. Under the Creative Commons Attribution license, you are free to copy, distribute, transmit, and adapt this work, including for commercial purposes, under the following conditions:

Attribution-Please cite the work as follows: World Bank. 2013. Inclusion Matters: The Foundation for Shared Prosperity-Overview. Washington, DC: World Bank. License: Creative Commons Attribution CC BY 3.0

Translations - If you create a translation of this work, please add the following disclaimer along with the attribution: This translation was not created by The World Bank and should not be considered an official World Bank translation. The World Bank shall not be liable for any content or error in this translation.

All queries on rights and licenses should be addressed to the Office of the Publisher, The World Bank, 1818 H Street NW, Washington, DC 20433, USA; fax: 202-522-2625; e-mail: pubrights@worldbank.org. 


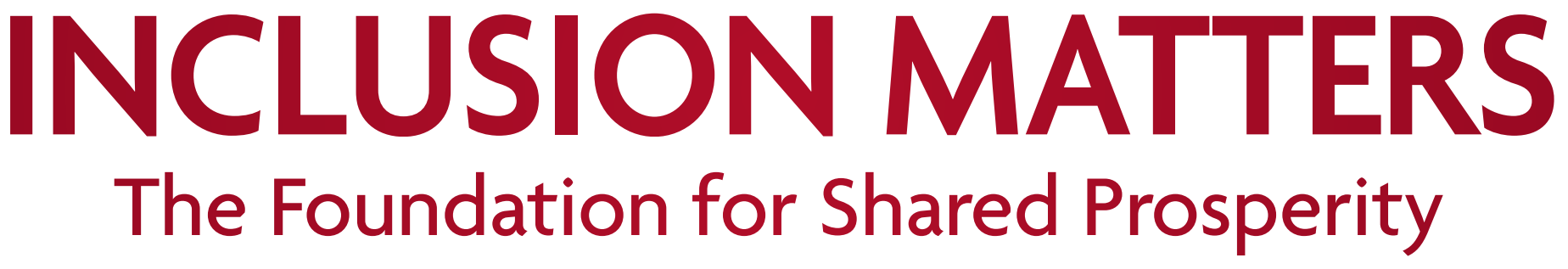



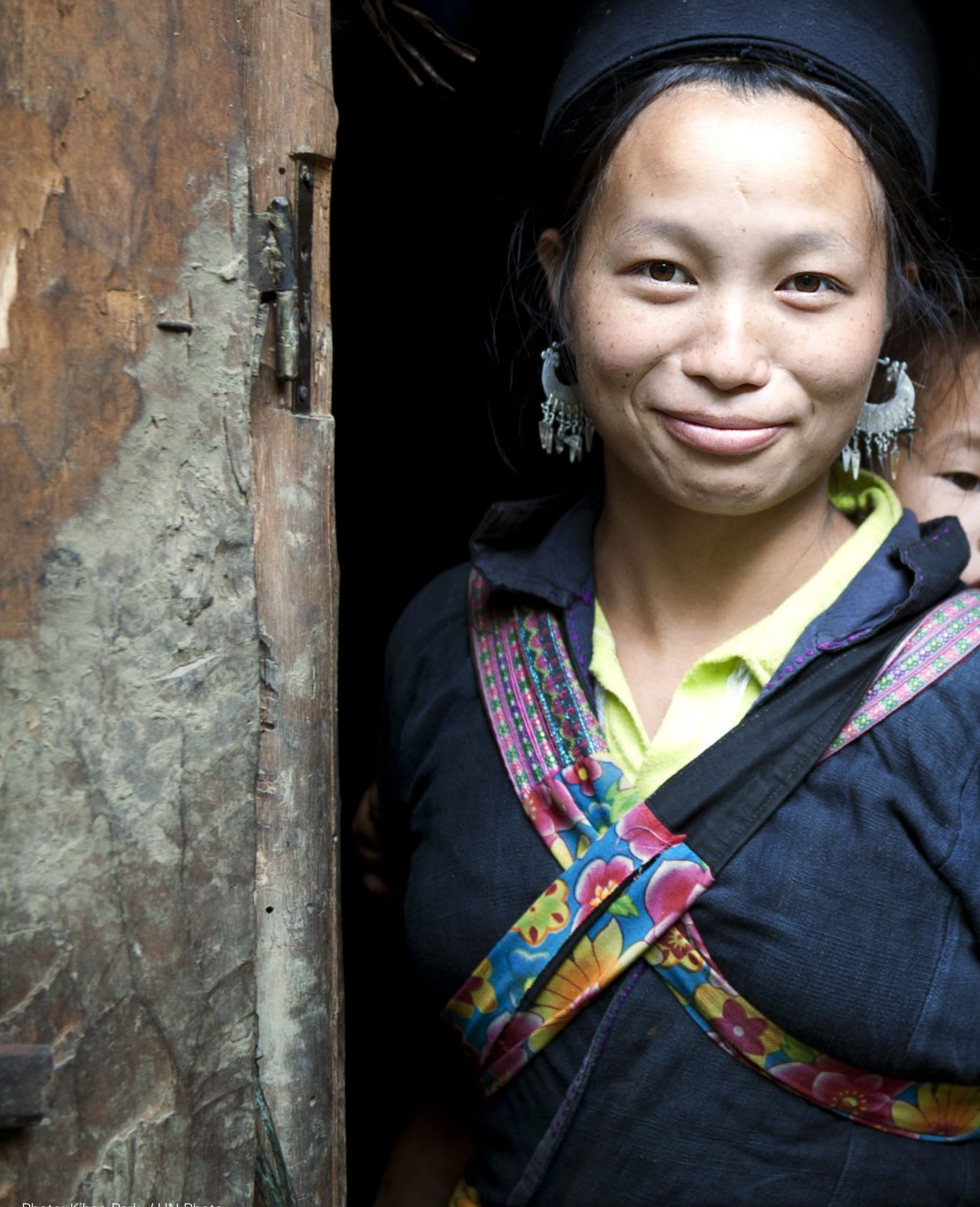


\title{
Table of Contents
}

\author{
1 Foreword \\ 3 Acknowledgements \\ 5 Introduction \\ 7 Clarifying Concepts \\ 9 Who Gets Excluded and How? \\ 11 Inclusion in What and How? \\ 11 Markets \\ 12 Services \\ 13 Spaces
}

14 Enhancing Social Inclusion by Improving Ability, Opportunity, and Dignity

$14 \quad$ Ability

$14 \quad$ Opportunity

15 Dignity

17 The Changing Context for Social Inclusion

21 Attention to Attitudes and Perceptions is Important in Addressing Social Inclusion

23 Social Inclusion Can Be Achieved

24 What Can Policies and Programs Do to Enhance Social Inclusion?

27 The Right Question

29 Concluding Reflections

30 References 


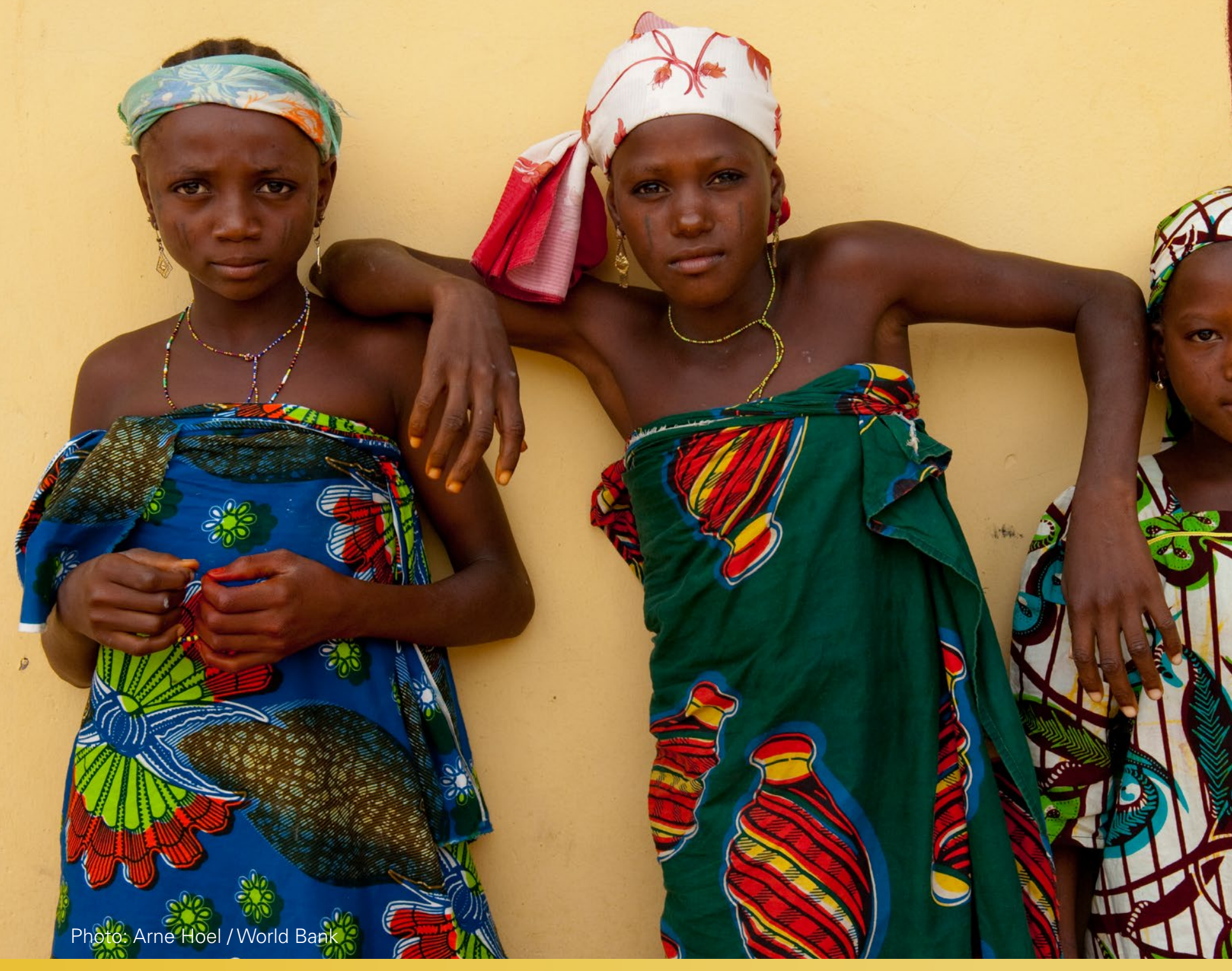




\section{Foreword}

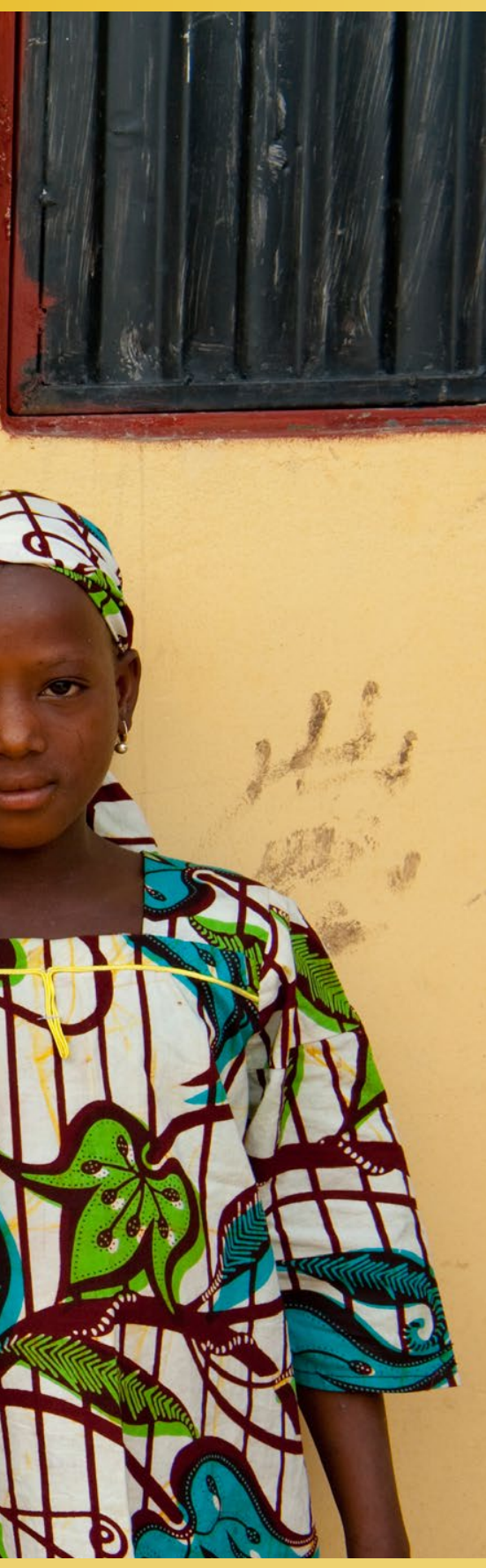

In every country, certain groups—whether illegal immigrants, indigenous people, or other minoritiesconfront barriers that prevent them from fully participating in their nation's political, economic, and social life. These groups are branded by stereotypes, stigmas, and superstitions. They often live with insecurity. And such disadvantages not only preclude them from capitalizing on opportunities to lead a better life, they also rob them of dignity.

In many countries, excluded people have organized to right a lifetime of wrongs. These newly active citizens include victims of violence who are demanding justice, or members of growing middle classes demanding greater voice in their countries' political processes. They come armed or simply angry, protesting in Brazil or India, and occupying Wall Street or Tahrir Square. Taken together, their outrage demonstrates a global crisis of inclusion.

At the World Bank Group, we have realized that confronting the need for social inclusion will prove vital if we are to meet our goal of building shared prosperity for all people. While great strides have been made in reducing extreme poverty, in country after country, groups remain excluded from development gains. A rising tide does not necessarily lift all boats.

Acknowledging this, in May 2013, the United Nations (UN) Secretary-General's High-Level Panel of Eminent Persons on the Post-2015 Development Agenda called for designing development goals that focus on reaching excluded groups. "Leave no one behind," they urged the Secretary-General, adding, "We should ensure that no person—regardless of ethnicity, gender, geography, disability, race, or status-is denied universal human rights and basic economic opportunities."

Including the excluded is a complex challenge. At the World Bank Group, we begin where we always do: by surveying, sifting, and analyzing the evidence. The result of that work is this evidence-based study of social inclusion. It is the first of its kind for the Bank Group. We believe it represents one of the most comprehensive reviews of social inclusion available. While more work is needed, our research allows us to say a few things with confidence:

Ostracized groups exist in all countries, rich and poor, democratic and not. They are often hidden from public censuses, made invisible by their fear of reprisal. Still, they can be found. In Vietnam, for example, where poverty reduction has been impressive, indigenous people are less likely to be covered by health programs or receive essential vaccinations. In the United States, African Americans were twice as likely as whites to be unemployed during the recent financial crisis. In Bolivia, ethnic minority Quechua-speaking women are 28 percentage points less likely to complete secondary school than Spanish-speaking Bolivian men.

Excluded groups are denied opportunities. Excluded groups are significantly less likely to receive the benefits of development investments. In Uganda, for example, where electricity coverage is low, 
almost half of respondents from the Buganda group reported having electricity, compared to less than 5 percent of the minority Lugbara and Ngakaramajong populations. The same breakdown appears in terms of access to clean water. Some excluded groups have been denied opportunities for hundreds of years, such as Native Americans in the United States.

Poverty and exclusion are not the same. In some societies, even the rich can be excluded, as might be the case with wealthy homosexual men in some African countries. The protest movements in the Middle East have been fueled in part by demands among middle-class citizens for greater inclusion in public decision making and accountability from political leaders.

Exclusion is costly. Measuring the cost of exclusion has methodological challenges, but the costswhether social, political, or economic-are likely to be substantial. Occupational segregation can restrict the free movement of talent and resources, resulting in productivity losses to an entire economy. One study found that exclusion of the ethnic minority Roma cost Romania 887 million euros in lost productivity. Studies in Bolivia estimate that ethnic exclusion reduces agricultural productivity by up to 36 percent.

Most importantly, we find abundant evidence that inclusion can be planned and achieved. Education represents an unparalleled agent for stimulating inclusion. Religious leaders and other champions of change can help excluded groups acquire voice and confidence. The march towards greater inclusion, however, is not linear. Expanding the rights of formerly oppressed people risks triggering a backlash from historically dominant groups, who see their interests threatened. The process of fostering inclusion is incremental. It requires time and unwavering commitment. Still, the benefits of persistently striving for inclusion are at once striking and numerous. Examples can be seen around the world, from the overthrow of apartheid in South Africa, to China's outlawing of foot binding, to the growing support that Brazilian police now provide to victims of rape. Exclusion is far from immutable.

Solving the problem of social exclusion is urgent. Tensions are rising around the world, due to demographic shifts, migration, food price shocks, and economic volatility. People fleeing war and extreme poverty often become the most excluded groups in host countries. In the future, moreover, climate change will likely result in mass migrations, as cities and countries confront extreme drought, storms, heat waves, and sea-level rise. Longstanding prejudices may result in excluded groups receiving blame for growing societal tension and competition for resources.

To move ahead wisely, we need a clear research agenda. We need better tools to measure the costs of exclusion and for diagnosing its root causes. We must also develop more sophisticated analyses of which strategies are most likely to foster social inclusion, and mechanisms for gauging when inclusion efforts are working and when they are not.

We offer this report with the hope that it will stimulate research, action, and a broader debate on social inclusion. Increased understanding of this crucial topic will strengthen efforts to deliver better results for the world's poor, and help achieve our shared goals of ending extreme poverty and building shared prosperity for all people. 
This report was prepared by a team led by Maitreyi Bordia Das, Social Development Department (SDV), under the guidance of Rachel Kyte, Vice President of the Sustainable Development Network (SDN) and Cyprian Fisiy, Director of the Social Development Department (SDV).

The core team comprised Sabina Espinoza, Gillette Hall, Soumya Kapoor-Mehta, Kamila Kasprzycka, Maria Beatriz Orlando, Juan Carlos Parra Osorio, Maira Emy Reimão, Lisa Schmidt, Sonya Sultan, Emcet Oktay Tas, and leva Žumbyte. In addition, Sabina Espinoza, Soumya Kapoor-Mehta, and Emcet Oktay Tas were part of the main writing team. Special thanks are due to Elizabeth Acul, Colum Garrity, Kyung Min In, Nona (Anju) Sachdeva, Syed Abdul Salam and Cristy Tumale from SDV for their outstanding support.

Background inputs were prepared by Taaka Awori (independent consultant), Sabina Espinoza, Patricia Fernandes, Roberto Foa (Harvard University), Rasmus Heltberg, Surinder Jodhka (Jawaharlal Nehru University, New Delhi), Soumya Kapoor-Mehta, Kamila Kasprzycka, Sadaf Lakhani, Rachel Marcus (independent consultant), Roberto Miranda (Inter-American Development Bank), Simon O'Meally, Maria Beatriz Orlando, Juan Carlos Parra Osorio, Beata Plonka (independent consultant), Graeme Ramshaw (independent consultant), Maira Emy Reimão, Audrey Sacks, Lisa Schmidt, Hilary Silver (Brown University), Li Shi (Beijing Normal University), Sonya Sultan, Emcet Oktay Tas, Francesco di Villarosa (independent consultant), Maria Cecilia Villegas, Xiaolin Wang (International Poverty Reduction Center in China), and leva Žumbyte.

The team would like to thank peer reviewers Dan Banik (University of Oslo and China Agricultural University), Francisco Ferreira, Arjan de Haan (International Development Research Centre, Canada), Jesko Hentschel, Andrew Norton (Overseas Development Institute), Dena Ringold, and Carolyn Turk for their insightful comments and for participating in the review meetings. Marianne Fay (Chief Economist, SDN), Elisabeth Huybens (Sector Manager, SDV when this report was conceived; now Sector Manager, Social Development, Europe and Central Asia Region) and Susan Wong (Sector Manager, SDV) also provided valuable comments and guidance.

Constructive comments were received at various stages of the review process from Motoko Aizawa, Beatrix Allah-Mensah, Kaushik Basu,
Tara Beteille, Ana Maria Muñoz Boudet, Franck Bousquet, Charles Cormier, Maria Correia, Alberto Coelho Gomes Costa, Anis Dani, Pyush Dogra, Mariana Felicio, Varun Gauri, Elena Glinskaya, Helene Grandvoinnet, Asli Gurkan, Sara Gustafsson, Bernard Harborne, Karla Hoff, Naila Kabeer (School of Oriental and African Studies, University of London), Sarah Keener, Jeni Klugman, Markus Kostner, Paul Kriss, Angela Nyawira Khaminwa, Andrea Liverani, Alexandre Marc, Robin Mearns, Bala Menon, Sarah Michael, Ambar Narayan, Deepa Narayan (international advisor), Claudia Nassif, Sarah Nedolast, John Newman, Clarence Tsimpo Nkengne, Asta Olesen, Pedro Olinto, Mario Picon, Hans-Otto Sano, Rodrigo Serrano, Ulrich Schmidt, Jordan Schwartz, Sudhir Shetty, lain Shuker, Varun Singh, Emmanuel Skoufias, Rob Swinkels, Sarah Twigg, Paolo Verme, Varalakshmi Verumu, Chaogang Wang, Gregor Wolf and Michael Woolcock.

The Social Development Sector Board helped to refine many of the ideas in this report. Discussions with Junaid Ahmad, Mariana Cavalcanti (Getúlio Vargas Foundation, Rio de Janeiro, Brazil), He Hsiaojun (International Poverty Reduction Center in China), Ricardo Paes de Barros (Secretariat of Strategic Affairs of the Presidency of Brazil), Dewen Wang, and Xiaoqing Yu helped in crafting the story line. Early findings of the report were presented at meetings and seminars organized by the Organisation for Economic Co-operation and Development (OECD), Swiss Agency for Development and Cooperation (SDC), United Nations Educational, Scientific and Cultural Organization (UNESCO), International Poverty Reduction Center in China (IPRCC), Institute for Studies on Labor and Society (IETS), and Overseas Development Institute (ODI), and participants provided valuable inputs.

The report drew upon a range of operational and analytical engagements that were supported by staff based in the World Bank country offices of Afghanistan, Brazil, China, Ghana, Poland, and Uganda. The support from the Nordic Trust Fund (NTF) and the Multi-Donor Trust Fund for Poverty and Social Impact Analysis (PSIA-MDTF) is gratefully acknowledged.

Finally, Fionna Douglas, Hendrik Barkeling, Doreen Kibuka-Musoke, and Ewa Sobczynska provided valuable support and advice. Bruce Ross-Larson facilitated a writers' workshop and Dick Thompson provided editorial support for the overview. 


\section{Social Inclusion}

- The process of improving the terms for individuals and groups to take part in society.

- The process of improving the ability, opportunity and dignity of people disadvantaged on the basis of their identity to take part in society.
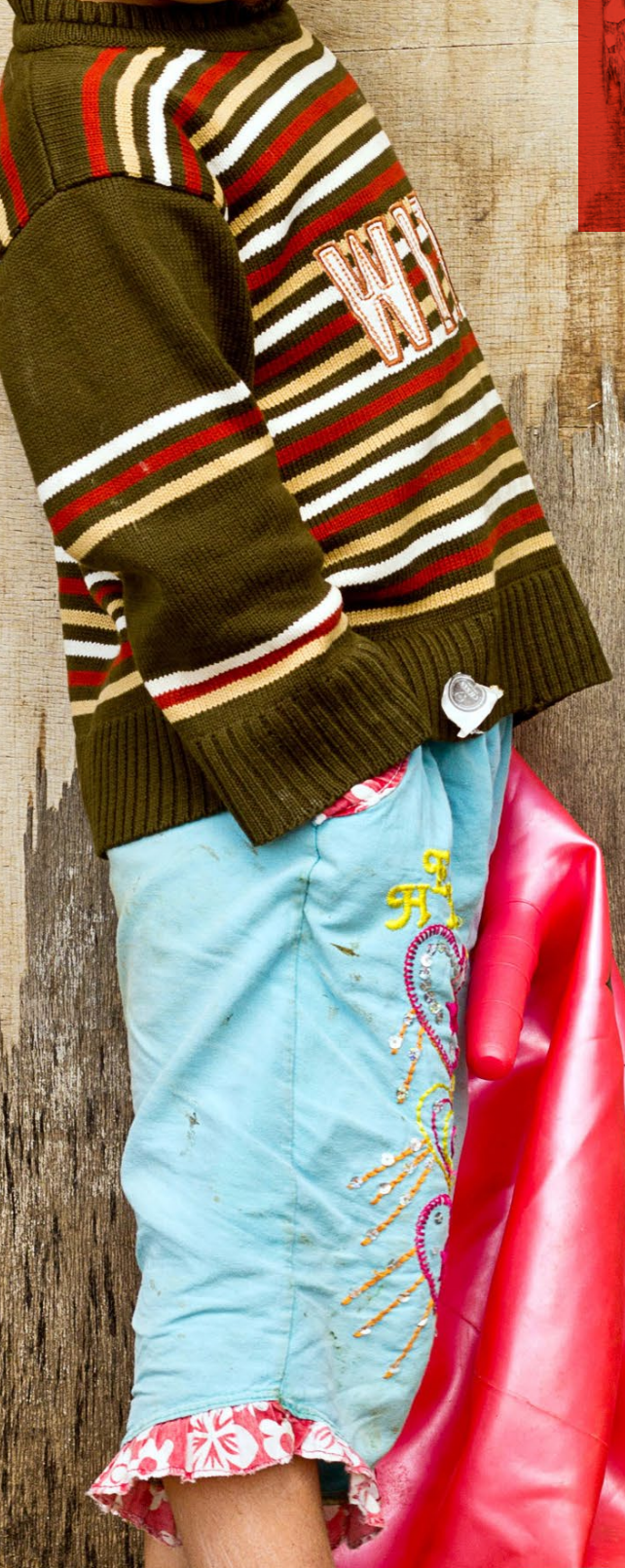


\section{Introduction}

The World Bank Group's focus on social inclusion began with the observation that even within countries, development investments produced unequal benefits. Further assessments revealed that groups with certain distinguishing characteristics consistently failed to benefit from a nation's progress. These groups were among the poorest in a nation, but they were not consistently the poorest. They were often, but not always, minorities. What set them apart was that they were members of excluded groups-indigenous people, new immigrants, people with disabilities, people with different skin tones, people who spoke the official language imperfectly. These were people branded by stigmas, stereotypes, and superstitions. They confronted unique barriers that kept them from fully participating in their country's political and economic life. They were excluded.

One of the world's greatest development efforts is coming to a close. The year 2015 marks the endpoint for achievement of the Millennium Development Goals (MDGs). In assessing the MDG response and charting a course for the next era of development, the United Nations Secretary-General's High-Level Panel of Eminent Persons on the Post-2015 Development Agenda (UN 2013) called for designing development goals that focus on reaching excluded groups. "Leave no one behind," it advised. "We should ensure that no person-regardless of ethnicity, gender, geography, disability, race, or status-is denied universal human rights and basic economic opportunities."

Along with global developments, the World Bank Group has announced two ambitious goals for itself: ending extreme poverty and promoting shared prosperity. Underlying the goals is the notion of "sustainability." A sustainable path for development and poverty reduction is defined as one that manages the resources of the planet for future generations, ensures social inclusion and adopts fiscally responsible policies that limit future debt burden (World Bank 2013b). As a recent World Bank Group publication notes:

A sustainable path toward ending extreme poverty and promoting shared prosperity would also involve creating an inclusive society, not only in terms of economic welfare but also in terms of the voice and empowerment of all groups.
An inclusive society must have the institutions, structures, and processes that empower local communities, so they can hold their governments accountable. It also requires the participation of all groups in society, including traditionally marginalized groups, such as ethnic minorities and indigenous populations, in decision-making processes. (World Bank 2013b, 33, emphasis added)

Social inclusion matters for itself. But it also matters because it is the foundation for shared prosperity and because social exclusion is simply too costly. There are substantial costs-social, political, and economic - to not addressing the exclusion of entire groups of people. The Arab Spring may have been the most costly recent reaction to the exclusion of educated youth-from labor markets but also, and perhaps mainly, from political decision making and accountability. Although there are significant methodological challenges in measuring the cost of exclusion, some efforts have been made. A World Bank report on the Roma (an ethnic minority in Europe) estimates annual productivity losses caused by their exclusion. It suggests that these costs could range from $€ 231$ million in Serbia to $€ 887$ million in Romania (de Laat 2010).

Exclusion has deleterious consequences for human capital development as well. For instance, a recent report finds that children with disabilities are less likely to start school than children without disabilities and have lower rates of staying in school (WHO and World Bank 2011). Similarly, women in India who experience spousal violence are less likely to receive antenatal care and more likely to have a terminated pregnancy or still birth, and their children are more likely to be stunted than are children of mothers who have not been abused (World Bank 2011a).

This report provides a frame of reference to help understand and move toward social inclusion. It is intended for policy makers, academics, activists, and development partners-indeed, anyone who is curious about what inclusion can mean and how it can be addressed in a world that is in the throes of formidable transitions. Although it does not provide definitive answers, it offers a definition and a framework to help advance the agenda of social inclusion. It builds 


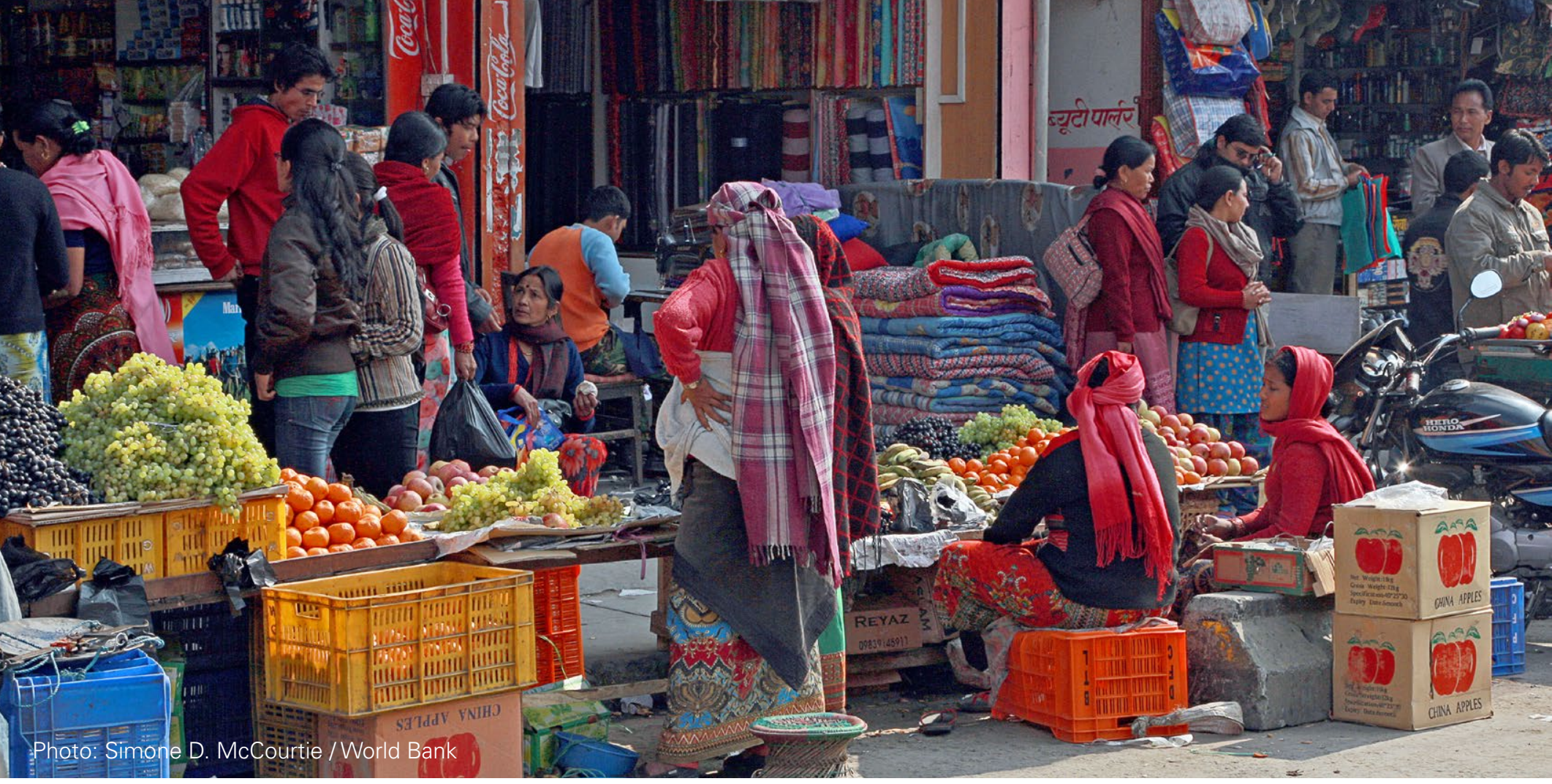

on the Bank's previous analytical work on themes that have touched upon social inclusion. It also draws on a review of relevant literature, analysis of survey data, some new qualitative work, and policy engagement with select countries.

This report is the Bank's first comprehensive examination of inclusion. It is certainly incomplete. It is hoped that this first effort prods and inspires further research by social scientists to broaden the understanding of the causes, consequences, and remedies of exclusion.

\section{There are seven main messages in this report:}

1. Excluded groups exist in all countries.

2. Excluded groups are consistently denied opportunities.

3. Intense global transitions are leading to social transformations that create new opportunities for inclusion as well as exacerbating existing forms of exclusion.

4. People take part in society through markets, services, and spaces.

5. Social and economic transformations affect the attitudes and perceptions of people. As people act on the basis of how they feel, it is important to pay attention to their attitudes and perceptions.

6. Exclusion is not immutable. Abundant evidence demonstrates that social inclusion can be planned and achieved.

7. Moving ahead will require a broader and deeper knowledge of exclusion and its impacts as well as taking concerted action.

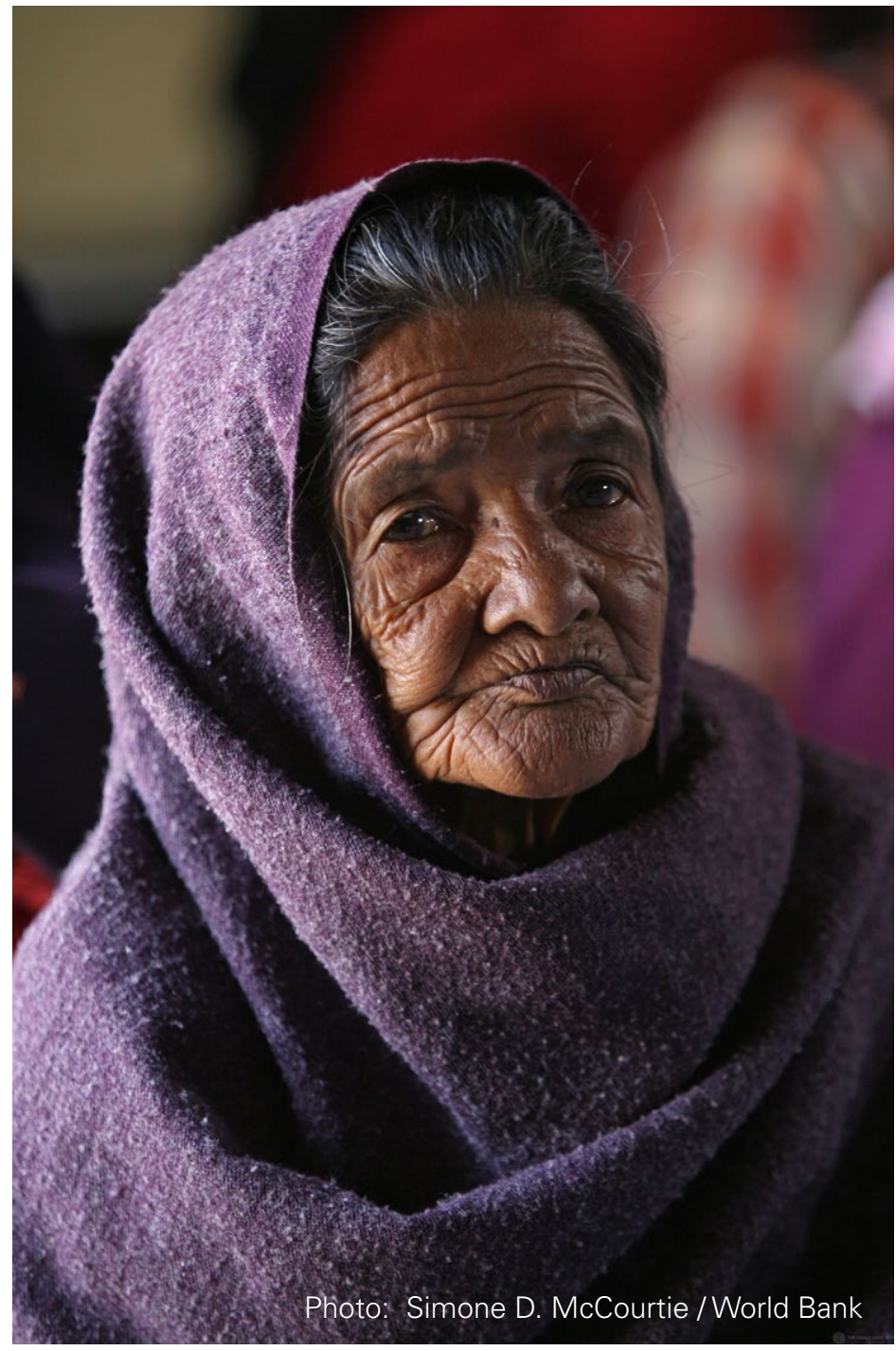




\section{Clarifying Concepts}

Although there is general agreement that social inclusion matters, there are few terms as abstract and political as social inclusion. It is notoriously many things to many people. Although it is true that the term is more political than analytical (Øyen 1997), it is also true that it has its roots in identifiable models of welfare and in principles of social justice and human dignity.

This report proposes defining social inclusion in two ways. The first is a broad sweep to guide policy makers. It states that social inclusion is:

\section{The process of improving the terms for individuals and groups to take part in society.}

A second, sharper definition takes into account how the terms of social inclusion can be improved and for whom. It articulates social inclusion as:

\section{The process of improving the ability, opportunity, and dignity of people, disadvantaged on the basis of their identity, to take part in society.}

People often find it easier to explain what social exclusion is. Yet even social exclusion is often lumped with the related concepts of poverty and inequality. Social inclusion may well be about reducing poverty-but it is often about more than poverty, and in some cases, it is not about poverty at all. Take the case of a homosexual man living in a rich neighborhood in any of several African countries. He may not be poor, but he is certainly excluded-and in some countries, at risk of death. Exclusion can intersect with poverty, deriving from a set of multiple, interrelated disadvantages that result in both economic and social deprivation (Silver n.d.). Understanding that "the poor" are not one homogeneous mass but are rather differentiated on the basis of occupation, ethnicity, place of residence, or race is central to developing effective inclusive policies.

Social inclusion takes poverty analysis beyond identifying correlates to uncovering its underlying causes. It asks questions such as why certain groups are overrepresented among the poor and why some people lack access to education, health, and other services or receive poorer-quality services. It exposes the multidimensional nature of chronic deprivation arising from social exclusion, which plays a key role in driving the more readily observable correlates of poverty (lack of schooling, poor health, and constrained labor market returns). It underscores that deprivation arising from social exclusion tends to occur along multiple axes at once, so that policies that release just one of these axes of deprivation, such as improved access to education, will not unleash the grip of others. It draws back the curtain on the norms and belief systems that underpin this multifaceted exclusion, which may be overt norms, such as apartheid in South Africa, or the result of intangible belief systems handed down through history.

Social inclusion is also not the same as equality. The term social inclusion can add to the idea of equality, but much more importantly, it can explain why some inequalities exist or why some are particularly durable (Tilly 1999). There are many ways that people can achieve fuller participation and inclusion, even if they lack an equal share of resources. At the same time, even people at the higher end of the 


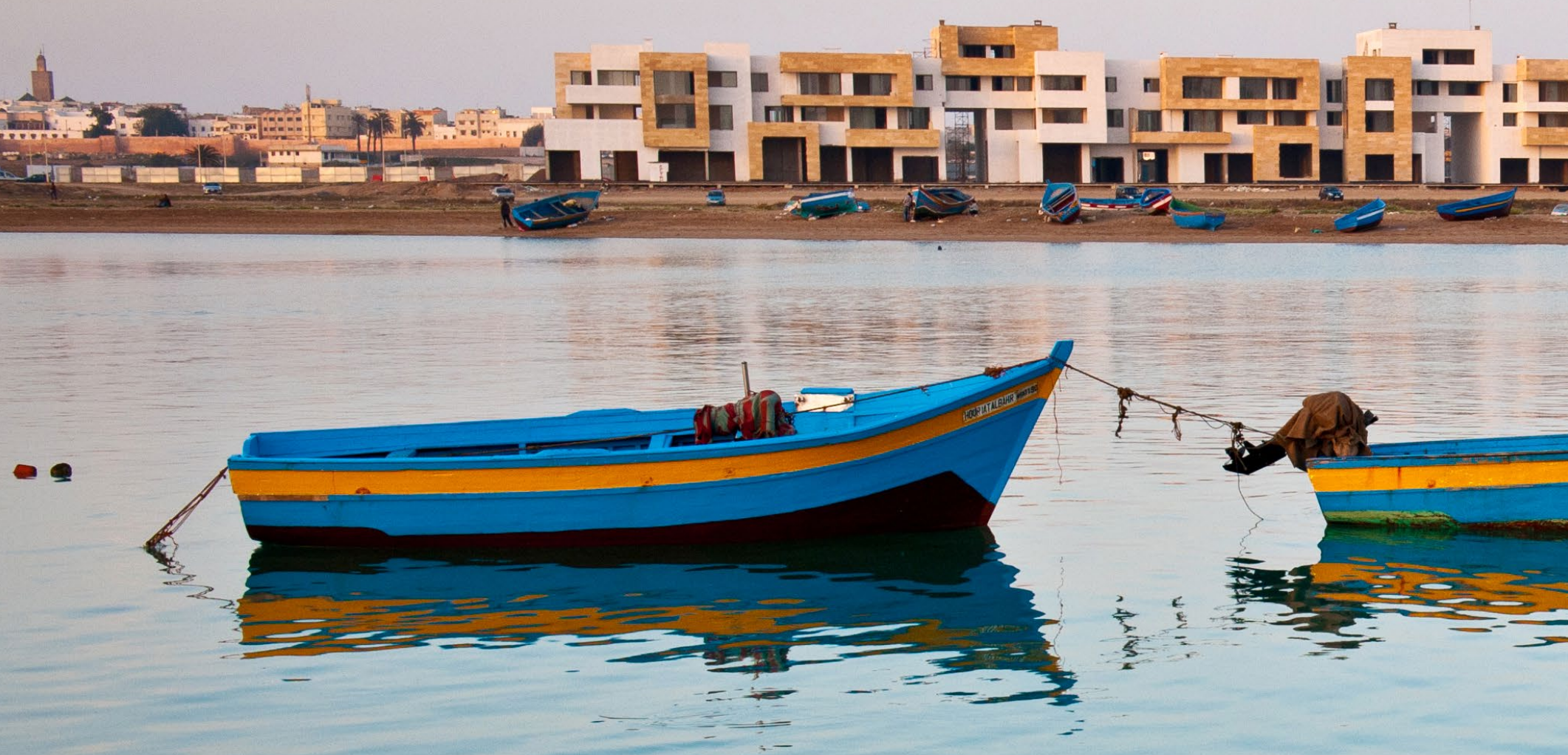

Photo: Simone D. McCourtie / World Bank

income distribution may face social exclusion through political persecution or discrimination based on age, gender, sexual orientation, or disability (Warschauer 2003). So exclusion can be horizontal, affecting several members of a group, whether poor or rich. It is a process, of which inequality is sometimes, but not always, an outcome.

Practitioners of development, who sometimes consider social inclusion too esoteric an idea, often ask how it could be quantified. How would one know when exclusion takes place and when inclusion is achieved? Such measurement is indeed important to establish the extent and depth of exclusion and to monitor progress toward inclusion.

There has been considerable progress in the area of measurement of human well-being, if not social inclusion, more directly. In fact, "happiness-based" conceptualizations of societal progress go back to the writings of Bentham and Mill. But over time, attention moved away from happiness to the measurement of real production (Galbraith 1998; Sen 2000). In recent years, there have been several significant initiatives to measure societal progress more comprehensively, and many have incorporated subjective reports of well-being.

The test of moving toward social inclusion is to move forward from the metrics to ask why certain outcomes obtain for certain groups, to focus on the drivers and processes of those outcomes. Doing so means persevering with questions, not being content, for instance, with the knowledge that certain groups are overrepresented among the poor or that some have worse human development outcomes, but rather asking why this is the case. It means building consensus around difficult answers that such questions will inevitably throw up. The narrative that is constructed as a result is the most important way in which social inclusion can have meaning. 


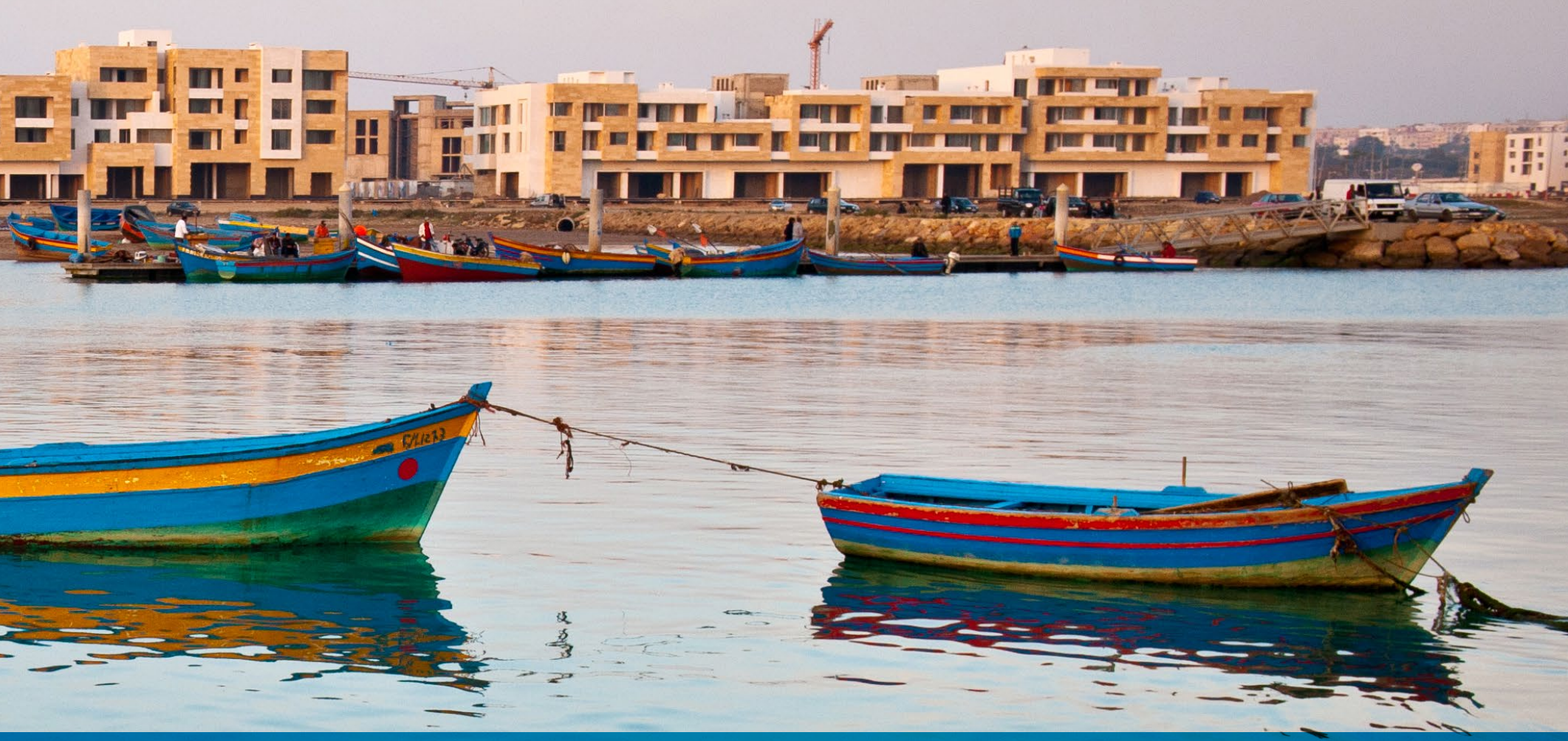

\section{Who Gets Excluded and How?}

The eyes of others our prisons, their minds our cages.

-Virginia Woolf, “An Unwritten Novel” (1921)
Individuals and groups are excluded or included based on their identity. Among the most common group identities resulting in exclusion are gender, race, caste, ethnicity, religion, and disability status. Social exclusion based on such group attributes can lead to lower social standing, often accompanied by lower outcomes in terms of income, human capital endowments, access to employment and services, and voice in both national and local decision making. Gaps between the attainment of males and females in a range of outcomes are well documented. People of African descent are still excluded in a variety of cultures. The caste system, peculiar to India and Nepal, stands out as an "ideal type" of exclusion, complete with an ideology and a hierarchy that has persisted through millennia. Religion continues to be a serious driver of exclusion. And indigenous people around the world continue to face exclusion that is rooted in large part in their displacement from their traditional lands (Hall and Patrinos 2012). 
Some identities that were not acknowledged as sources of social exclusion or inclusion some decades ago are acknowledged as such today. They include sexual orientation, nationality, and HIV/AIDS. The lesbian, gay, bisexual, and transgender (LGBT) community, for instance, is targeted for exclusion in many, if not most, cultures. With huge waves of migration, both within countries and across them, the identity of migrant groups and individuals has come under special scrutiny, especially in developed countries, which are grappling with ways of integrating nonnatives.

Individuals are members of different groups at once and may be excluded through one of their identities but not another. The notion of "intersectionality" is based on the understanding that people are simultaneously situated in multiple social structures and realms (figure 1). However, when they intersect, identities can produce a multiplication of advantage or disadvantage. For instance, the intersection of gender, age, ethnicity, and place of residence can have significantly more deleterious effects than the effects of gender alone. Take the case of Bolivia, which has high levels of secondary school attainment. Figure 2 shows that being a Spanish-speaking woman in Bolivia reduces the probability of completing secondary education by 5 percentage points, compared with being a Spanish-speaking man. If this Bolivian woman were a man who belonged to the Quechua people, the probability of completion would decline by 14 percentage points. If she were a Quechua woman, it would decline by 28 percentage points. Similarly, the intersection of social and spatial characteristics is a common marker of disadvantage.

Groups are heterogeneous, so exclusion within groups exists as well. Characteristics of some members of the group, such as socioeco-

\section{Figure 1: People Have Multiple, Intersecting Identities}

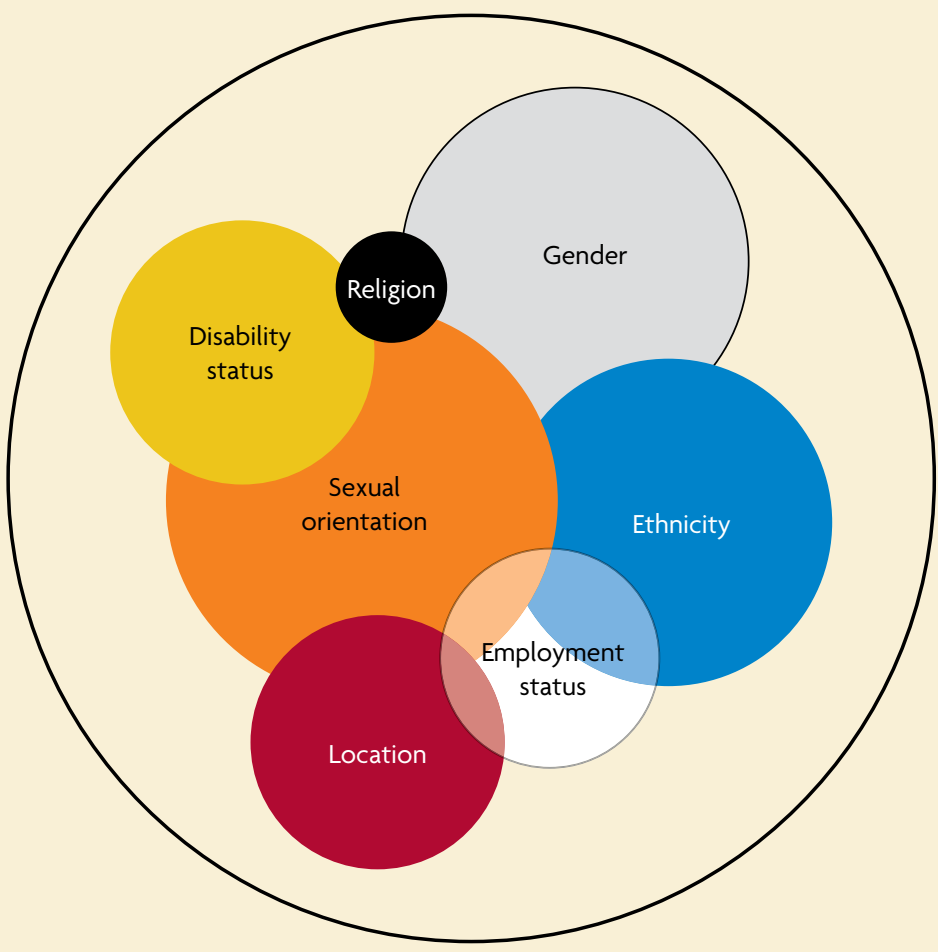

Note: Figure shows illustrative example of types of identities. The size of each bubble denotes the importance of an identity, which can vary across individuals, groups, and even the same individual over time.

\section{Figure 2: Intersecting Identities Transfer Cumulative Disadvantage: Secondary School Completion in Bolivia}

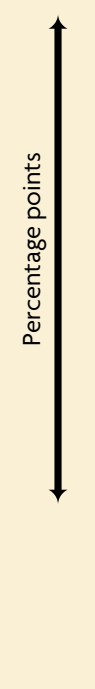

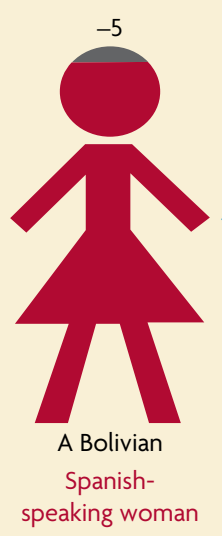
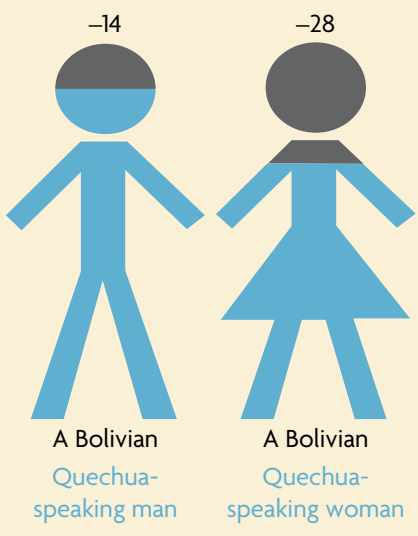

Source: World Bank, based on data from Minnesota Population Center 2011 and Bolivian National Institute of Statistics 2001.

Note: Figure shows secondary school completion marginal effects, using men and Spanish mother tongue as reference group, for people 25 years and older, controlling for age, age-squared, and urban/rural residence. All values are significant at the 1 percent level. 
nomic status, place in the life cycle, or circumstances (such as widowhood), can also bestow advantage or disadvantage. Where social security systems are primarily informal, many elderly people are now at risk of ill treatment. Similarly, without concerted action on poverty, employment, and human development, countries with large youth cohorts are not being able to realize their "demographic dividend." Skin tone can matter as well; individuals within the same race or ethnicity (indeed even within the same family) who have lighter skin appear to have better outcomes, ranging from chances of getting married (especially of women) to employment (Villarreal 2010; Hersch 2008; Jha and Adelman 2009).

Exclusion plays out through both tangible and intangible practices and processes. Although it is most evident in differences in "tangible" outcomes, it is rooted in intangible social norms and beliefs, which in turn lead to stereotypes, prejudices, and stigmas. These intangible features are socially constructed and played out by both the excluder and the excluded. For example, stereotypes about groups can be so ingrained in the labor market that hiring managers or peers do not even realize that they have them (see Deshpande and Newman 2007; Loury 1999) or may not consider them stereotypes but facts. Stereotypes of "lazy" Roma or of women having low commitment to the labor market are so internalized by the majority that they are often regarded as truisms, even though they are not borne out by data on labor force participation (de Laat 2010). Sometimes the words that describe certain practices say a lot about the social acceptance of exclusion. For instance, the term eve teasing is used in South Asia as a flippant euphemism to signify sexual harassment of women in public places, and both the term and the practice are treated with the same indulgence.

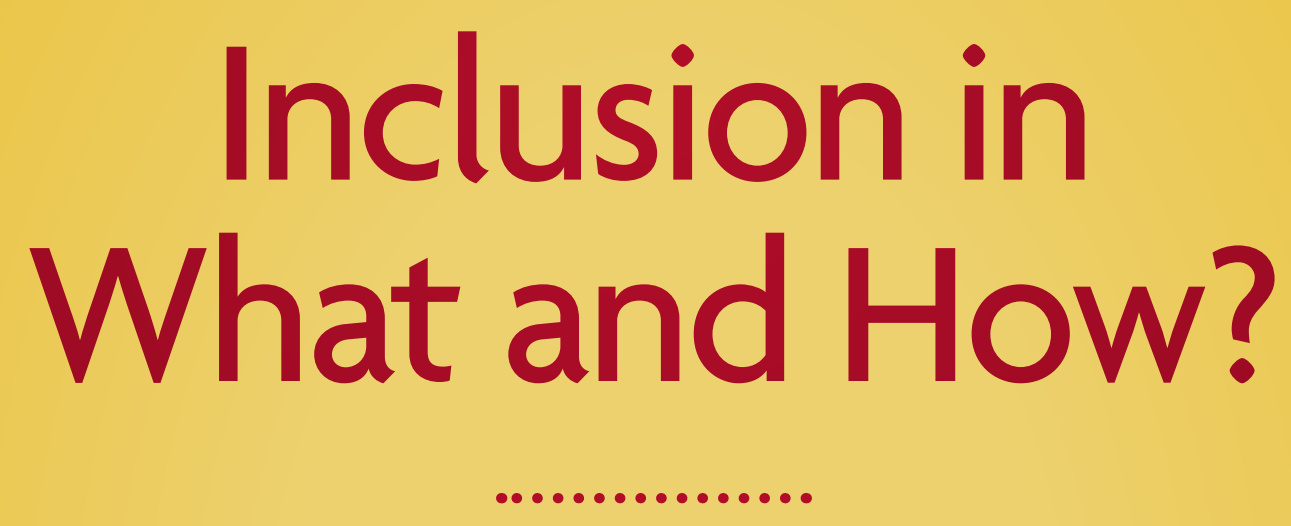

This report provides an illustrative set of interventions, but any policy or program can be designed and implemented using a social inclusion lens.

Individuals and groups want to be included in three interrelated domains: markets, services, and spaces (figure 3). The three domains represent both barriers to and opportunities for inclusion. Just as different dimensions of an individual's life intersect, so do the three domains. Intervening in one domain without consideration of the others is likely to be one of the most important reasons for the limited success of inclusion policies and programs.

\section{Markets}

In their day-to-day interactions, people engage in society through four major markets-land, housing, labor, and credit-all of which intersect at the individual and the household level. Land, for instance, has been a historical driver of exclusion. The roots of exclusion of indigenous populations the world over, for instance, lie, in significant part, in the appropriation of their lands by their colonizers or by other nonindigenous groups. Major social upheavals have been caused by unequal agrarian relations, which at once straddle land and labor markets. In many parts of the world, women's historical lack of access to land has underpinned their lack of enforceable property and other rights. Exclusion from access to land affects both rural and urban populations. Urban land markets are notoriously skewed in favor of the rich and powerful; laws that govern their use and sale have been, of late, the subject of considerable debate. One of the manifestations of exclusion from urban land markets is unequal access to housing, with negative externalities in other areas. On the side of inclusion, land ownership can confer status and security (see Deininger and Feder 1998; Carter 2000).

Like land markets, labor markets are crucial sites for the play of social relations. They reflect the existing and historical inequalities in a society and are tied up with social stratification (see Polanyi 1944). 
Figure 3: Propelling Social Inclusion: A Framework

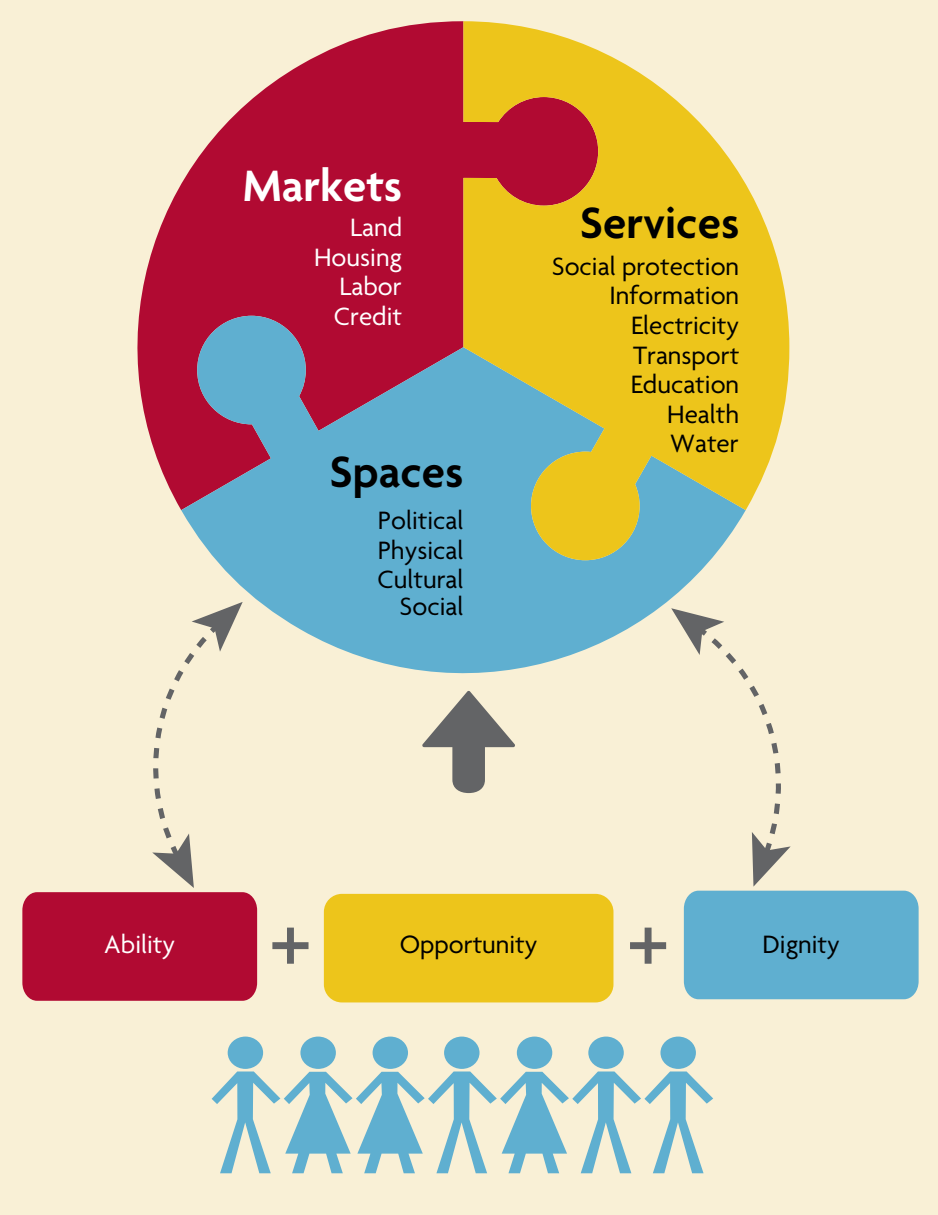

For instance, slavery was at its core an occupational division of labor, with slaves working on farms and plantations. Caste, similarly, is a system of occupational segregation that became a form of social stratification, systematically excluding certain groups.

Disparity in labor market outcomes is most visibly demonstrated by the gap in earnings between preferred and excluded groups. In a study of 18 Latin American countries, Ñopo, Atal, and Winder (2010) find sizable gender and ethnic wage gaps between indigenous and nonindigenous populations. Occupational segregation by race, ethnicity, and gender is pervasive and contributes to the exclusion of certain groups from preferred jobs.

Land and labor markets are intricately linked to credit markets, especially in developing societies. The most extreme form of coalescence between the three types of markets is forced labor, which still persists in many countries. In Nepal, for instance, as part of the Kamaiya and Haruwa/Charuwa systems, indebted families, often from the historically disadvantaged castes, pledge themselves or their children to work because they cannot pay debts to moneylenders, who are often also landowners. Such labor arrangements involve agricultural workers agreeing to bondage in return for advance payments of salary from landlords at rates far below minimum wages or in lieu of loans at very high interest rates. Workers attached to the labor market through bonded labor mechanisms are rarely able to accumulate sufficient savings to repay the bond and are thus effectively in serfdom for the remainder of their lives. The transition from bonded labor to greater labor freedom is fraught with risk, because freedom severs connections with former "employers," who are also "patrons," who in addition to providing employment provide housing, protection, and in-kind transfers (World Bank 2011b).

The global push toward "financial inclusion" may be overtly about the penetration of financial instruments into untapped markets, but it is equally about social inclusion. Social assistance and wages, even for unskilled workers, are increasingly being channeled through banks and other formal payment mechanisms. Under these circumstances, lack of access to financial systems becomes an important axis of exclusion. Financial services are, moreover, increasingly tied up with access to digital technology, such as smart cards and automatic teller machines, which may create an additional layer of exclusion for individuals and groups that are either uneducated or otherwise already disadvantaged. Only 15 percent of adults in fragile and conflict-affected states have bank accounts (Demirgüç-Kunt, Klapper, and Randall 2013). In more developed financial markets, too, broad economic shocks and poor access to credit can hurt minorities disproportionately, as evident in the mortgage crisis in the United States, where African Americans and Latinos were disproportionately affected relative to their share of mortgage originations (Bocian, Li, and Ernst 2010).

\section{Services}

Access to services is essential to improving social inclusion. Health and education services enhance human capital. Social protection services cushion vulnerable groups against the effects of shocks and promote their well-being. Transport services enhance mobility and connect individuals to opportunities. Water and sanitation are essential for good health. Access to energy is important for livelihoods and for human capital. And information services enhance connectedness and allow individuals to take part in the "new economy."

Overall, subordinate groups tend to have lower access to basic services. In rural areas of the Lao People's Democratic Republic, for example, estimates suggest that a higher proportion of women from the excluded community (non-Lao-Tai) never attended school (34 percent compared with 6 percent of Lao-Tai women). Men from the excluded group fare better than women but still worse than the majority group: 17 percent of non-Lao-Tai men never attended school compared to 4 percent of Lao-Tai men. Disparities are also visible in access to health services. In Vietnam, where poverty reduction has been impressive, indigenous peoples are less likely to be covered by health programs or receive vital vaccinations, despite impressive improvements in overall access to health (Hall and Patrinos 2006, 2012). Data from African countries show that groups that speak minority languages as their mother tongue typically have lower access to services such as water and electricity. In Uganda, for instance, 
Figure 4: Access to Electricity Varies by Ethnicity in Uganda, 2010

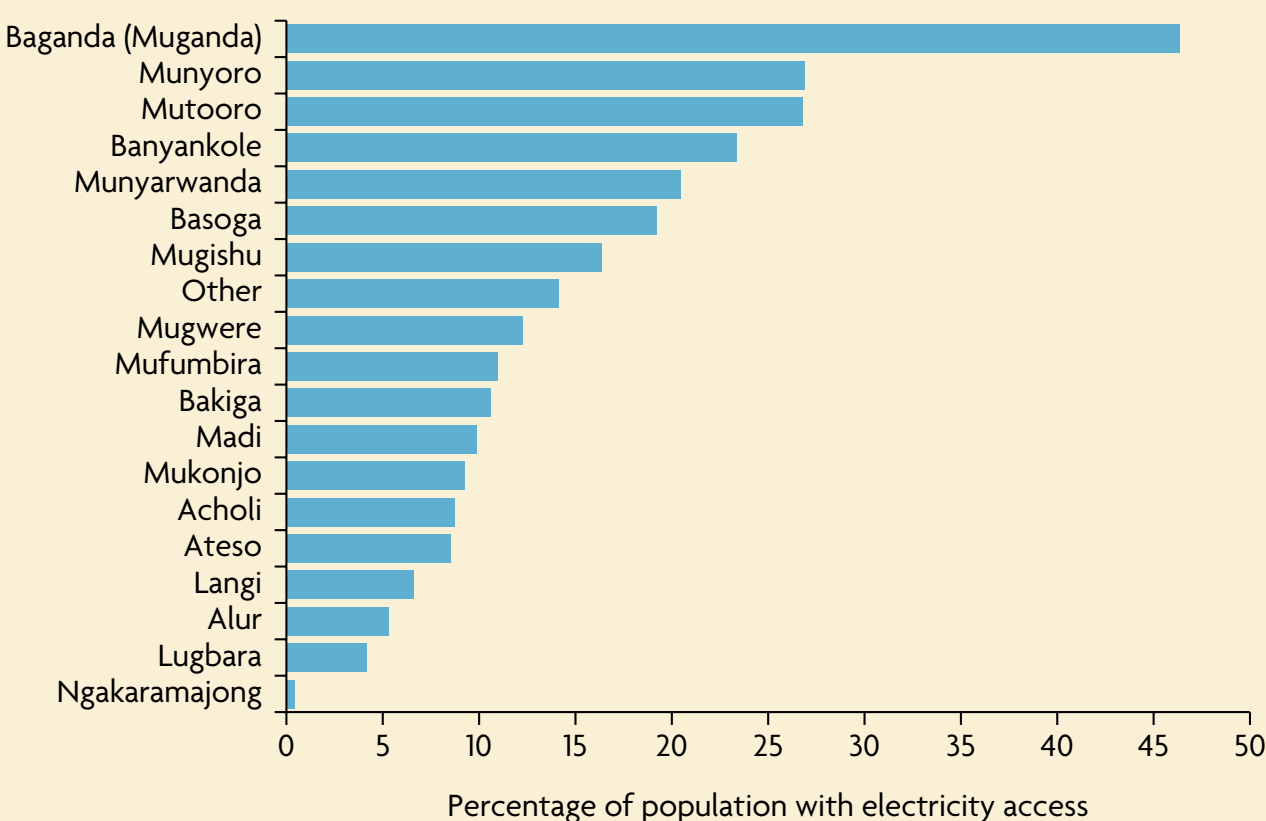

Source: World Bank, based on data from the Uganda Demographic and Health Survey 2011 (UBOS and ICF 2012).

Note: Names of ethnic groups appear as they are in the survey. where electricity coverage is low in general, almost half the Muganda respondents in the 2011 Demographic and Health Survey (UBOS and ICF 2012) reported having electricity, but less than 5 percent of the Lugbara and Ngakaramajong did (figure 4). Similar results show up in self-reported water insecurity from the Afrobarometer: the Langi, the Ateso, and the Alur report the highest incidence of having experienced water insecurity "most or all the time," and the Mutooro, Mukiga, and Munyankole are most likely to report never having experienced such insecurity.

\section{Spaces}

Physical spaces have a social, political, and cultural character that solidifies systems and processes of exclusion. The most overt example of exclusion is when physical spaces are reserved for dominant groups, such as whites-only clubs during apartheid in South Africa or during slavery in the United States. The literature suggests a subculture created by dominant groups in the United States to implicitly exclude minorities even when they can afford to buy homes in their neighborhoods. Neighborhoods thus become "white" or "black"; the term "white flight" is used to document the departure of white families when black people start to move into their neighborhoods. Black neighborhoods are often considered poor or "bad" or unsafe, reflecting at once a judgment on their social and economic character. Similarly, there is evidence to suggest that Dalits in India and Nepal are still sometimes barred from entering temples and other physical spaces that are considered "pure."

Excluded groups can react to their disadvantage by claiming certain spaces. Clustering in certain geographical areas can serve as op- portunity enclaves for the excluded, who, when excluded from the primary market, concentrate in markets for the excluded and use them for social and economic mobility (Wilson and Portes 1980; Portes and Jensen 1989). This phenomenon has been documented, for instance, for Cubans in Miami and other immigrants, who skirt labor market discrimination by consolidating their positions in clusters of the excluded. Not all strategies of clustering necessarily lead to social mobility, however. The perverse impact of clustering is illustrated in differential child mortality patterns in Ghana, where the Ga have higher levels of mortality than other ethnic groups. Weeks and his colleagues (2006) found a close association between differences in child mortality (by ethnicity) and residential clustering in Accra.

Because social inclusion is also at its core about accountability of the state to its citizens, it is as much about occupying political space as it is about having an equitable share in markets and services. It is not just poor people or traditionally excluded groups that demand greater political space and voice. Increasingly, educated people who feel excluded from a range of spaces are clamoring for greater participation. Poverty and minority status often compound the lack of access to political space. Many countries have seen a rolling back of state power since the 1980s, accompanied by a widening of economic opportunities. Yet state power continues to underpin many processes of exclusion and inclusion, and rent-seeking becomes an important process of exclusion. For instance, the power to award mining leases or to sit in positions that can influence public sector hiring offers ample scope for consolidating social, political, and economic space. Although politicians do not necessarily or exclusively favor their own ethnic or cultural group, groups with little or no political representation risk their interests being excluded from consideration (Marcus et al. 2013). 


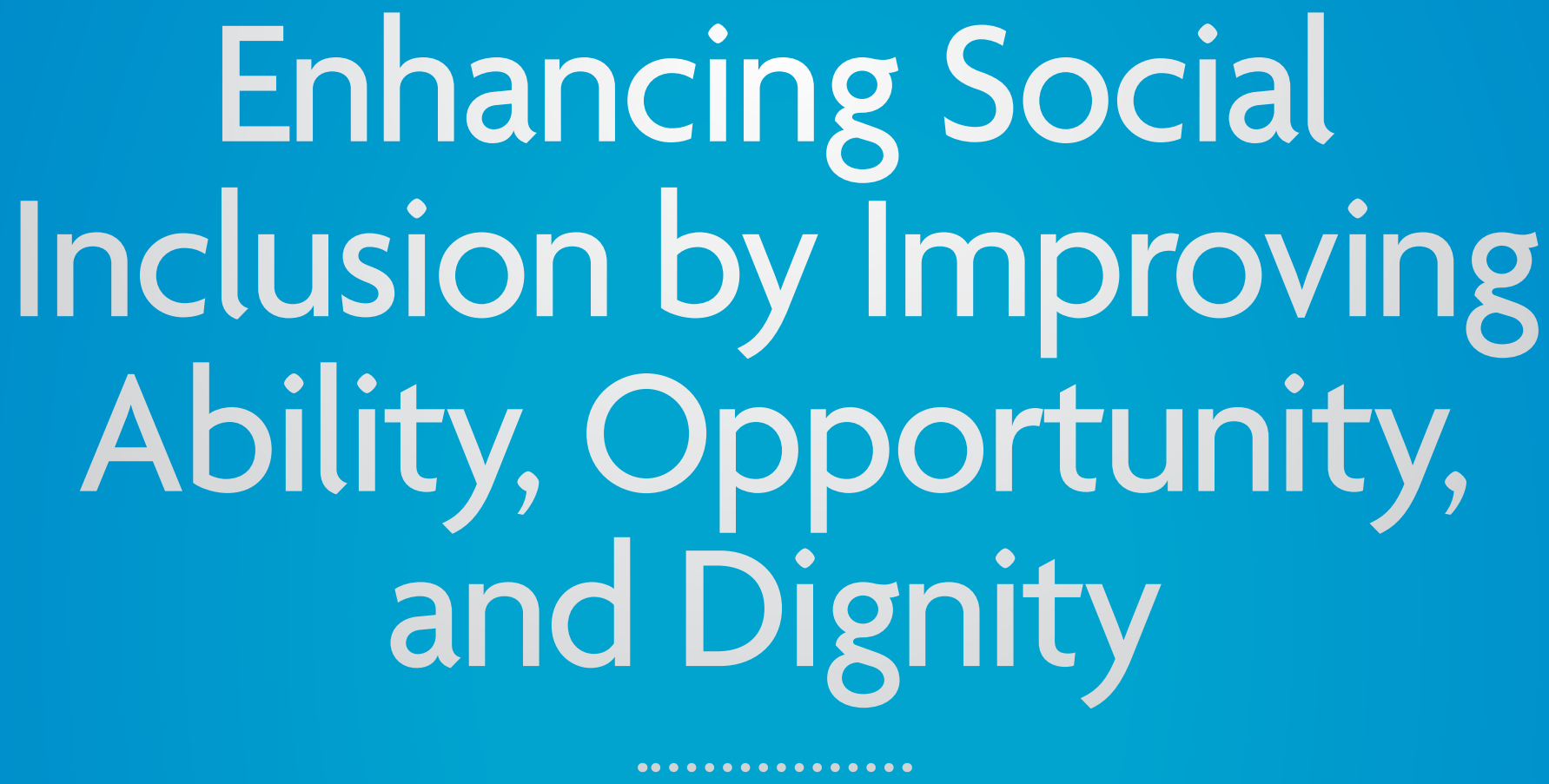

\section{Ability}

This report uses the ideas of ability, opportunity, and dignity and applies them to excluded groups. Ability, for instance, is innate to individuals, but, when measured through achievement tests, it may not always be randomly distributed. Instead, it may be socially mediated. A child who performs poorly on standardized tests at an early age may be affected by a range of background processes. These processes can include the fact that she was born with low birthweight to a very young mother and may not have had the parental stimulation that her peers in more advantaged circumstances had. These cumulative disadvantages are often systematically distributed by race, ethnicity, or place of residence. The literature on early childhood education indicates that the brain starts to develop in utero, and although brains are elastic enough to compensate for maternal or other in utero deprivations, they may not be able to fully do so. In addition, when children are deprived of stimulation and nutrition in the early months and years of life, their development is permanently affected.

The ability of an individual is also affected by the people she sees around her and whom she regards as reference models. Borjas (1992) outlines the notion of "ethnic capital" to show that individuals who are members of high-performing groups tend to perform better. This report argues that reference groups and role models are important in the "capacity to aspire," to use Appadurai's term. When individuals from disadvantaged groups see others around them performing at a low level, they set a much lower bar for themselves than they would have if they had belonged to a high-performing group. In addition, they may internalize exclusion in such a way that they do not even bother to try for better outcomes, knowing that people from their group are discriminated against. Elmslie and Sedo (1996) propose the idea of "learned helplessness" to show that negative events, such as an episode of discrimination, can lead to a decrease in learning ability. Exclusion, therefore, can create resignation at both the group and the individual level, which in turn diminishes human capital, constrains effort, and becomes somewhat of a self-fulfilling prophecy.

\section{Opportunity}

Inequality of opportunity is one of the major constraints to the realization of human potential. Recent work on the Human Opportunities Index ( $\mathrm{HOI})$ underscores this and focuses policy attention on investments that equalize opportunities at the beginning of the life cycle. The underlying assumption is that equalizing the supply of services will provide all individuals with an equal chance of translating their capabilities into enhanced well-being.

Providing full opportunity is not only an institutional challenge in many countries; the process of expanding opportunities can itself be exclusionary, constraining both the supply of and demand for opportunity.

Take the case of health facilities in remote areas where indigenous women live. The remoteness of their habitations means that providing them with the same quality and quantity of services as available to their urban counterparts is fiscally and institutionally challenging. 
Figure 5: Migrants in Urban China Speak of "Being Looked Down upon" by Locals, 2011

a. By age

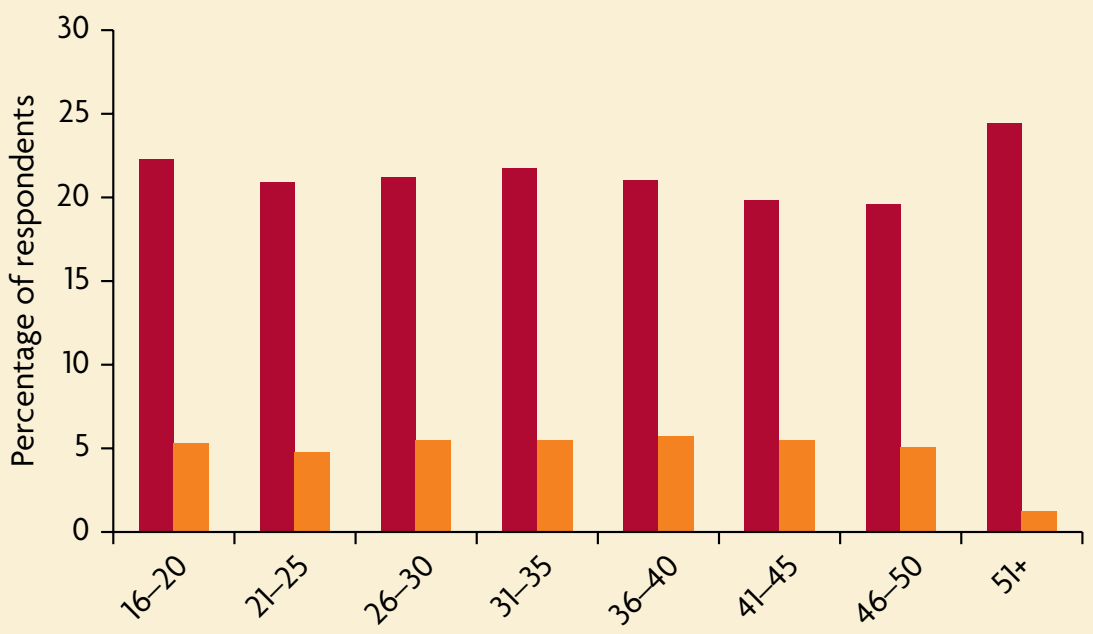

b. By education

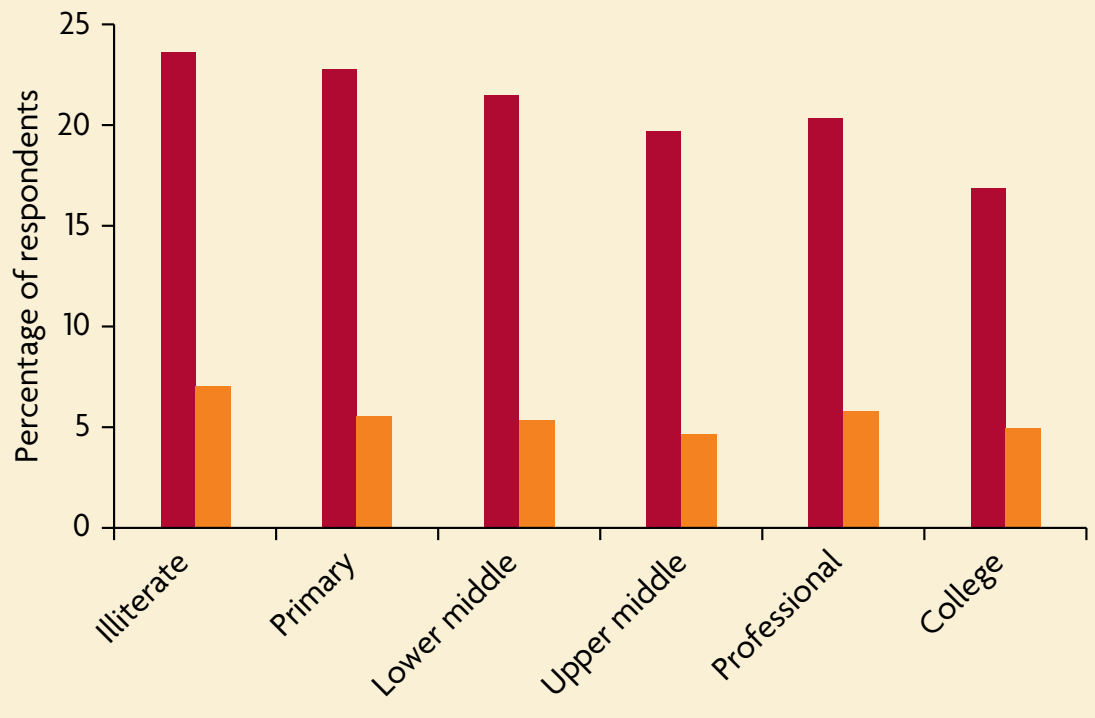

Agree Completely agree

Source: Shi 2012.

Note: Based on responses to the question, "Do you agree with the view that migrants are always looked down on by locals?" in the 2011 Migrant Survey conducted by the National Health and Family Planning Commission of the People's Republic of China. people and even legal citizens who lack documents to prove their residency or eligibility for various benefits. In still other cases, such as the Roma in many European countries, the excluded group hides itself from official surveys and censuses so that it can meld into the statistics of the majority. In figurative terms, dignity and recognition are linked to the way subordinate groups are treated by dominant groups and by the state. This treatment includes contempt for their cultures and practices and intentional or unintentional stereotyping that prevents them from fully taking part in society.

Tools are being developed to measure when individuals are being accorded dignity or treated without it. The empirical literature on dignity has been led by medical ethicists and advocates of respectful treatment of patients, especially the terminally ill, the elderly, and people with significant physical and cognitive impairments, at the hands of medical providers. For example, using data from the Commonwealth Fund 2001 Health Care Quality Survey of 6,722 adults living in the United States, Beach et al. (2005) analyze the association between two measures of respect (involvement in decisions and treatment with dignity) and patient outcomes (satisfaction, adherence, and receipt of optimal preventive care). After adjusting for respondents' demographic characteristics, they find that people who were treated with dignity had a higher probability of reporting satisfaction. As measures of dignity are still being developed, the terms dignity, respect, and recognition are often used interchangeably.

A recent survey in China of 128,000 migrants in urban areas asked respondents whether they thought migrants were "always looked down upon" in the cities in which they lived. Between one-third and one-fourth of respondents thought they were always looked down upon by locals-a finding that varied little with age or education level (figure 5). Feelings of being looked down upon increased with length of stay, suggesting that migrants encountered unpleasant behavior if they stayed long enough and interacted with more people (Shi 2012). 


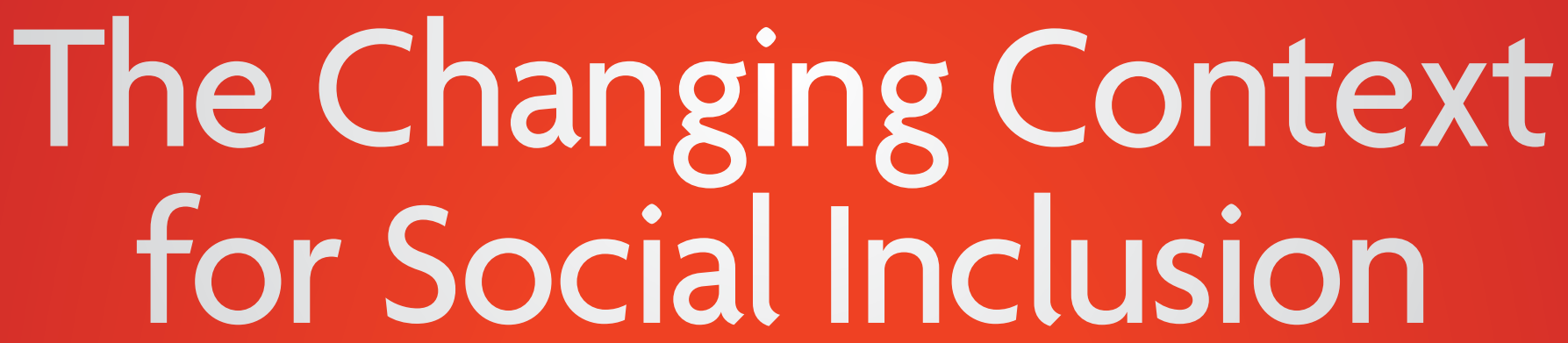

Much of today's global political upheaval can be linked to demographic, spatial, economic, and knowledge transitions that are transforming societies. The cumulative impact of the transitions of the past several decades has changed the profile of the global community and reshaped some of the social inclusion issues. The cumulative impact of these large-scale transitions has changed the context for inclusion by creating new opportunities for both inclusion and exclusion.

Complex demographic transitions have significant social impacts. Lower fertility and mortality rates are transforming age structures and living arrangements. Increasing numbers of the elderly mean that countries have to provide new ways of dealing with a large new cohort. Globally, the youth cohort is the largest in history, living mostly in developing and conflict countries. Population "pyramids" (box 1) are history. Consequently, reaping the demographic dividend requires concerted action to include young people in markets, services, and spaces, as well as skillful management of the political economy.

Additionally, current trends suggest that migration is likely to become a more dramatic and volatile demographic process than fertility or mortality. Europe is the largest hosting region. Its fertility rate is below replacement levels, indicating that unless birth rates rise over a sustained period, it will continue to have to import labor.

Migration within countries is also becoming larger in size and significance. The ongoing internal migration in China, for example, is the greatest and fastest movement of people in history, creating, among other things, shortages of urban services. Simultaneously, natural disasters, war, human trafficking, and economic recession are affecting migration patterns. All of these trends have a bearing on inclusion. For example, some countries and regions are witnessing high levels of hostility and resistance to migrants.

Urbanization was one of the most dramatic transitions of the previous century, and it will continue to unfold in the present one. At the individual and household level, urbanization offers the possibility for social mobility through a range of new opportunities. Migrants from rural areas move to cities and towns seeking new jobs, business opportunities, and education. Cities and towns also offer a differ- ent social milieu. Old norms and values give way to new and more diverse ones. However, not all social processes in urban areas are necessarily positive for excluded groups. Cities are increasingly polarized between people who have access to basic services and people who do not.

The slums in Brazil, known as favelas, are a case in point. Recognizing that favelas are a visual testimony to the country's inequality, Brazil adopted a mantra of moving from "divided cities" to "integrated cities."

Inequality within cities is also one of the root causes for the crime that has beset many cities. Over time, violence can become institutionalized, making it difficult to dismantle. Governance challenges in urban areas contribute to some groups feeling left out and having few opportunities for voice and redress. Core government functions can be taken over by land mafia, drug lords, and other extortionists. Mental health issues, substance abuse, and poor security all affect individuals more negatively in urban areas. Excluded groups live in areas that expose them to these negative factors more intensely.

One of the most profound transitions of this century is occurring as a result of climate change. It is already having rapid and catastrophic consequences on livelihoods, crops, and ecosystems. A recent report portends a scenario of a world that will be $4^{\circ} \mathrm{C}$ warmer in 2100 than in preindustrial times, leading to catastrophic heat waves, droughts, and floods in many regions (World Bank 2013a). Periods of climate-related stress, such as a drought, affect food availability, with people in conflict-affected areas hit hardest. Sen (2001) argues that food insecurity during periods of climatic stresses is higher in countries affected by conflict, because, unlike peaceful countries, regimes in conflict end up spending more on the military than on social programs and have poorly functioning markets and services. Conflict can affect agricultural production, for instance, by blocking the ability to import (UN 1993), by preventing access to farmlands and removing men from farming. These fragile populations often take refuge in countries with greater food security, but their presence can exacerbate tensions. 


\section{Box 1: Population Pyramids Are History}

Transitions in fertility and mortality and uneven migration patterns will make population pyramids extinct by 2050 , in all except the very high fertility countries. Figure B.1.1 shows age structures of three very different contexts: Uganda, where the fertility transition has been slow and late; Poland, which has very low fertility and low mortality; and the Arab Republic of Egypt, which falls in between these two scenarios. The pyramids show that by 2050, half of Uganda's population will be below 20 years of age; Egypt's population, which is young now, will be older and replaced by a much smaller cohort of young people; and Poland will have a full-fledged aging crisis. Each of these three scenarios underscores the need for planning and vision.
Figure B.1.1 Population Pyramids in Uganda, Poland, and the Arab Republic of Egypt, 1950, 2010, and 2050
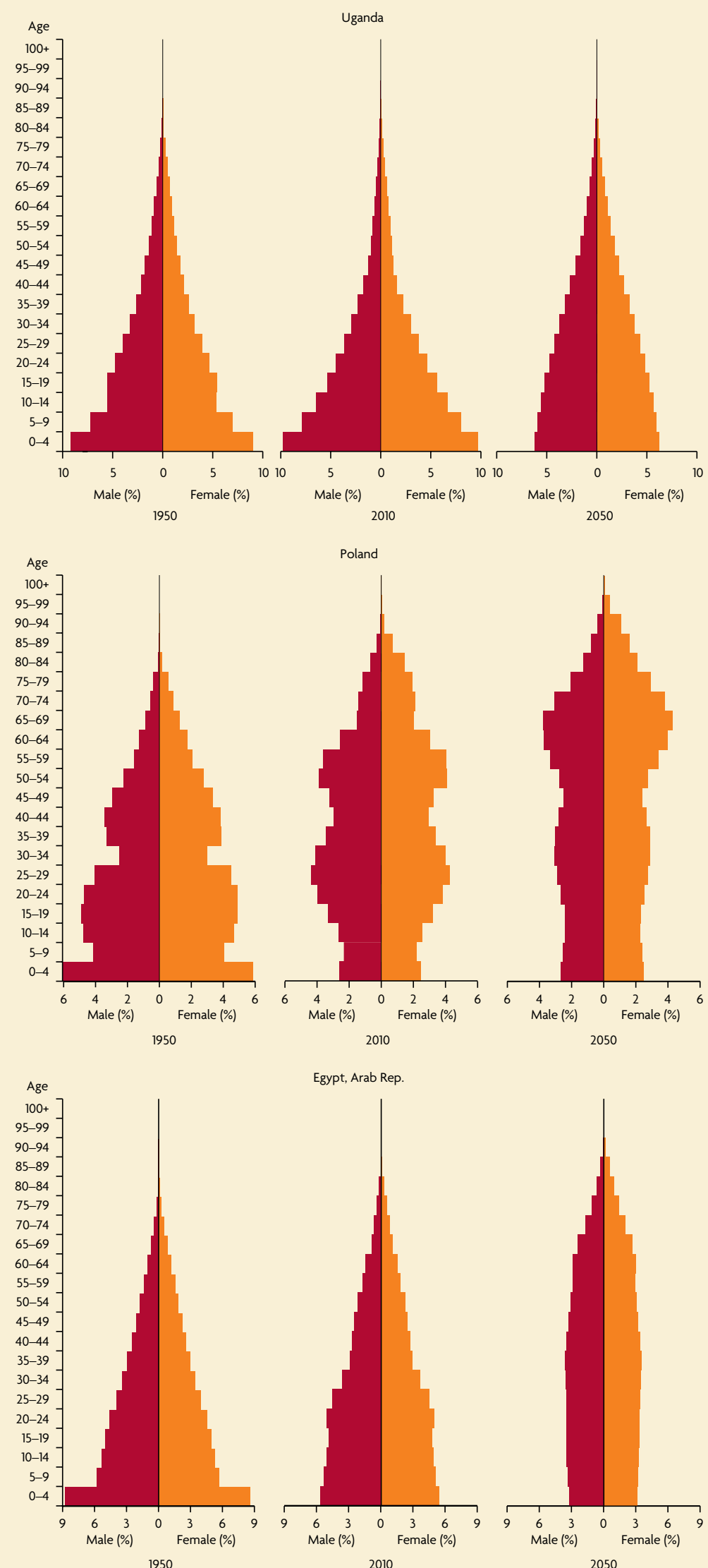

Egypt, Arab Rep.
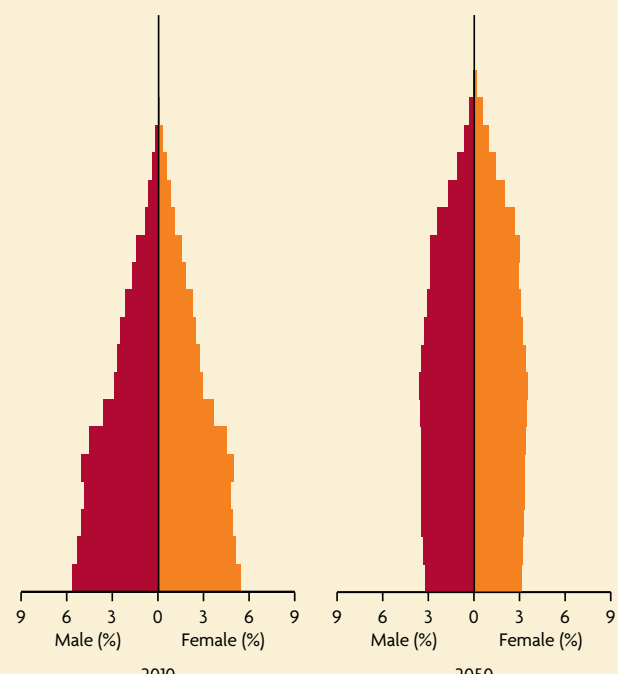

Source: World Bank, based on data from UN 2011. 


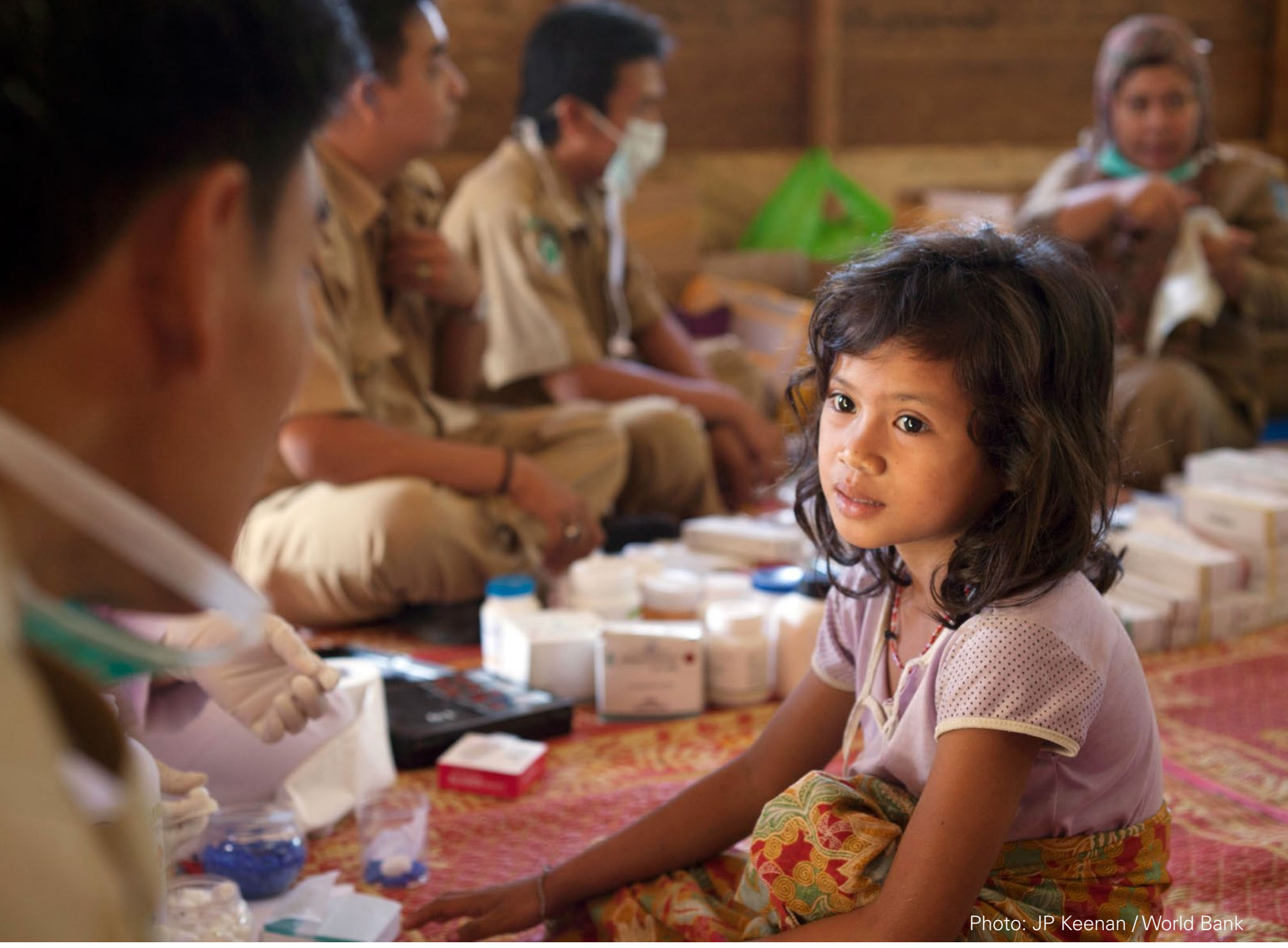

In tandem with, and underlying, other transitions over the last few decades are deep economic transitions. Globalization and regional integration, coupled with substantial reforms at the national level, have led to impressive growth and poverty reduction across the globe. As a consequence, a large cohort has now "graduated" to the middle class (Ferreira et al. 2013; Kharas and Gertz 2011; Dadush and Shaw 2011), implying a change in societal values and aspirations. The middle class is often the harbinger of change. Its support is critical to achieving the goals of social inclusion, partly because the relationship of the middle class to the state is quite different from that of the poor to the state. The middle class demands voice and accountability as a right; the poor can often be reduced to a supplicant by a strong state. Simultaneously, revolutions in knowledge, social networking, and citizen action have shown that aspirations, when unfulfilled, can create unique challenges for governments. Although inequality trends are highly heterogeneous across countries, income inequality is growing in the most populous countries like China and India. Finally, food security remains a challenge for most developing countries, with excluded groups and people who live in remote areas at greatest risk.

Education is another powerful force that is also changing the social context. Education is the unparalleled agent of social change and one that has expanded across the board, even in the poorest countries. A new cohort of young people has attainments, aspirations, and hopes that are quite different from those of their parents' generation.

In Sub-Saharan Africa, for instance, there was a fivefold increase in gross secondary school enrollment, from 7 percent to 36 percent, between 1970 and 2009 (WDI database). At the global level, the corresponding figure nearly doubled, from 36 percent to 68 percent. Education changes relationships of power within society and within households. Groups that were considered subordinate acquire voice and confidence when they are educated. They tend to be more assertive in holding the state and service providers accountable and in demanding dignity and respect from groups that were considered dominant. At the household level, educated young women have greater say in decision making and are able to access opportunities outside their homes in ways that their mothers never did. Their education changes intrafamily power relations.

A large body of literature focuses on the enormous impact that education can have on women's inclusion into markets, services, and spaces. When young women in Bangladesh were asked during focus group discussions how education had changed their lives, they poignantly described "being able to speak" as the most important gain (World Bank 2008). Yet ensuring decent quality of education remains a challenge. Additionally, educational institutions can be important spaces of exclusion. 
Men are disturbed not by things, but by the view which they take of them.

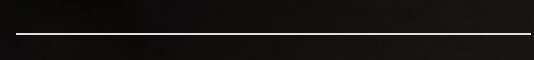

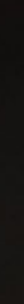

-Epictetus 


\section{Attention to Attitudes}

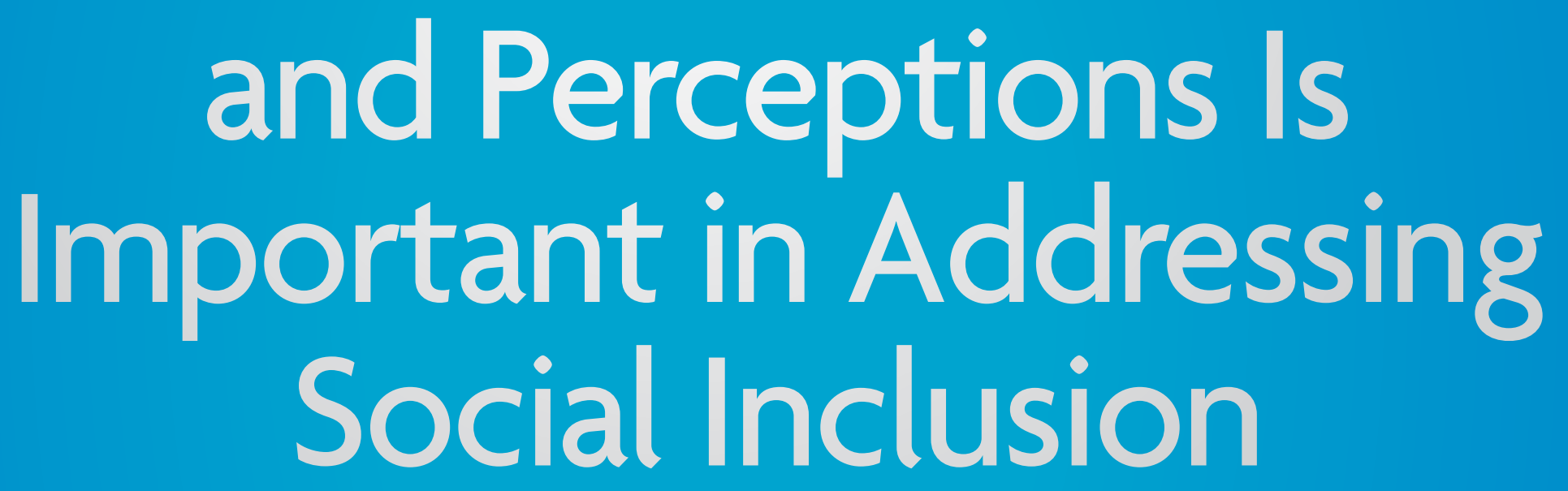

$\bullet \bullet \bullet \bullet \bullet \bullet \bullet \bullet \bullet \bullet \bullet \bullet \bullet \bullet \bullet \bullet$

Attitudes and perceptions matter for social inclusion because people act on the basis of how they feel. Their feelings of being included and respected are central to the opportunities they access and the ways in which they take part in society. Conversely, which groups get included and excluded, and on what terms, is shaped by people's attitudes about each other and about themselves.

The importance of attitudes and perceptions also spills over to levels above the individual. A large body of literature shows that prejudices, stereotypes, and misperceptions affect the way policy is implemented and even designed. This report shows that attitudes play a key role in the treatment of individuals and groups, both by other members of the society and by the state. Attitudes and perceptions also mediate social inclusion and shine a light on the processes through which exclusion takes place. Perceptions of unfairness and injustice and frustration with social and political institutions or with the society at large often reflect individuals' feelings of powerlessness. Feelings of fairness, justice, and "being part of society" can be manifestations of how much the society recognizes, respects, and listens to its members.

People's attitudes are often related to outcomes. Attitudes toward women's education, access to jobs, and leadership positions have a strong association with poor outcomes for women. Analysis of the World Values Surveys data conducted for this report, for instance, finds an inverse relationship between gross tertiary school enrollment rates for women and negative attitudes toward higher educa- tion for women. In Australia, New Zealand, and some Scandinavian countries, tertiary school enrollment among women is almost universal, and discriminatory attitudes toward access to higher education are very low. Attitudes regarding women's access to jobs are far less favorable in countries that have the lowest female labor force participation rates (less than 20 percent), including Egypt, Iraq, Saudi Arabia, Pakistan, Algeria, Jordan, and the Islamic Republic of Iran (figure 6 ). There also seems to be a relationship between attitudes toward women taking up leadership positions and their becoming leaders. Countries where fewer respondents say that men will make better political leaders are also the ones with the highest share of women parliamentarians (for example, Andorra, Sweden, Canada, Finland, Argentina, and the Netherlands).

Attitudes and perceptions are shaped by history, culture, and the way institutions have evolved over time. Take the case of perceived inequality and its acceptance in societies. Analysis of the World Values Surveys data conducted for this report suggests a nonlinear relationship between the extent of aversion to inequality and observed inequality. Australia and many countries in Europe have both low inequality and a low appetite for it. Some countries in Latin America (for example, Chile, Argentina, Uruguay, and to some extent Brazil) have high levels of measured inequality, but their aversion to it looks quite similar to other countries with much lower levels of inequality.

Citizens' views about the extent of fairness in their country often reflect deeper issues of inclusion and exclusion in society. This report 
finds, for instance, based on data from the Afrobarometer, that a majority of citizens in African countries feel that their country treats people unequally. This finding may be indicative of the fact that exclusion is a problem for many, rather than a few, and that the state is perceived as catering to the needs of a small section of society.

Perceptions about unfairness in Africa are substantiated by other trends in some countries. Africa's economic growth over the past decade was driven largely by mineral extraction, with the benefits concentrated among a few. Economic power is closely related to political power and representation in decision making, which in turn affects the allocation of public expenditure and can lead to disparities in opportunities. Income inequality, for example, has risen considerably in the last three decades throughout Sub-Saharan Africa. In 2010, Africa was the second most unequal region in the world (after Latin America), and 6 of the world's 10 most unequal countries worldwide were located in Southern Africa (AfDB 2012). Perceptions about inequality in non-African contexts may be shaped, similarly, by underlying trends in those contexts.

\section{Figure 6: Countries and Areas Where People Say Men Have More Right to Jobs Also Have Lower Labor Force}

Participation Rates for Women, 2005-08

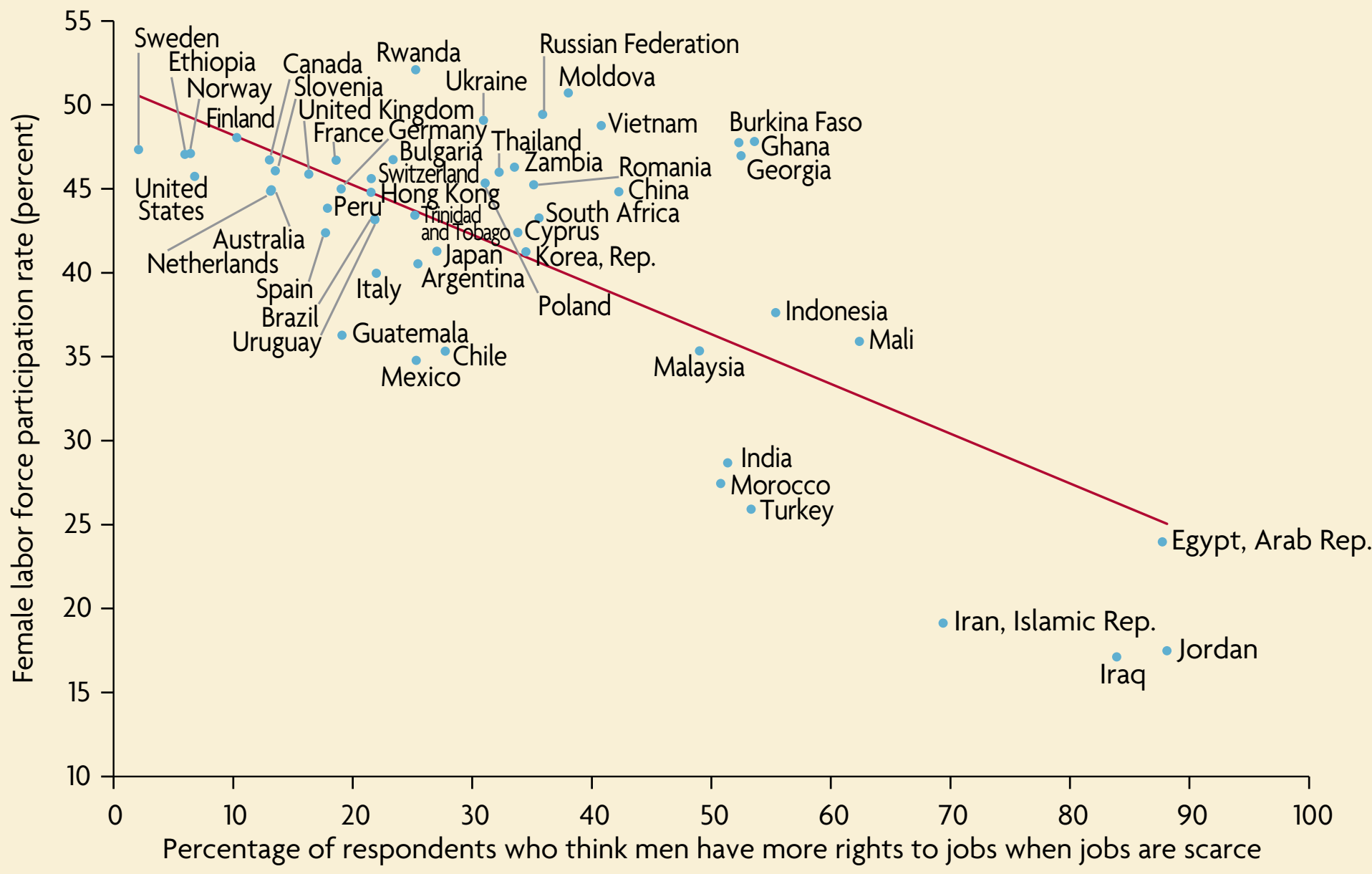
participation).

Note: Values correspond to data that were available for both variables within a span of two years. Data are latest available between 2005 and 2008. 


\section{Social Inclusion Can Be Achieved}

This report is an unequivocal statement that change is possible, that policy makers, activists, development partners, and others who care about justice and shared prosperity can steer change toward social inclusion. Exclusion is not embedded in culture and immutable. Change may happen by stealth or by design. It may happen through discrete events or through gradual processes that culminate over time.

Change is rarely linear. Attempts to make change inclusive may involve tradeoffs, creating both winners and losers. There can be pushback from the dominant groups when previously subordinate groups feel included and break the norms. Push-back can come with active retaliation, setting back the process of change.

Examples of change toward inclusion abound in history. South Africa, for example, moved from institutionalized segregation toward an ideal of a "rainbow nation" in a matter of two decades. Foot-binding, an ancient tradition in China, was curtailed and eventually disappeared following an intense social campaign and prohibition by law. The articulation of social exclusion in Brazil that started with a widespread belief in a "racial democracy" came to accept that discrimination on the basis of race has held some groups back. The exclusionary system of informal local justice in Bangladesh, the Shalish, has been transformed by greater voice and participation. In a region where women's role in society is confined to the private sphere, higher educational attainment among women in Jordan has become the rule rather than the exception.

The state has the preeminent role in promoting change toward inclusion, but other actors play important roles too. In fact, it is the interplay of state and nonstate actions that leads to inclusion. Catalysts and champions of change toward social inclusion, for instance, often come from the elite. The abolition of slavery in the United States, the end of foot-binding in China, and the end of apartheid in South Africa were all the product of social movements led by elites. Some of them came from excluded groups, as in the case of South Africa; others came from dominant groups, as in the case of the United States. In many countries, the role of religious leaders in both resisting and propelling change has been considerable. The role of business leaders in promoting social inclusion is also well recognized. Finally, civil society movements and collective action by excluded groups have

\section{A new and sweeping utopia of life ... where the races condemned to one hundred years of solitude will have, at last and forever, a second opportunity on earth.}

\section{- Gabriel García Márquez, Nobel Acceptance Speech}

historically pushed agendas for social inclusion by taking up specific "wrongs" that society needs to correct. More recently, the media has been known to play a significant role in changing mindsets and creating awareness against exclusion (Trujillo and Paluck 2012).

Moving from exclusion to inclusion does not happen overnight; it is important to have a long-term view. Social inclusion requires overcoming negative beliefs and stereotypes about excluded groups, which cannot be undone in a few years of "inclusive policy." Timing is therefore of the essence; the impacts of some changes may be felt years into the future or may well be the unintended consequences of policy or other developments. Similarly, the impact of change on groups can vary, and what is considered costly for some groups today may have positive outcomes in the future or vice versa.

Countries that are successful in addressing social exclusion usually have strong institutions. The strength of institutions lies in large part in their agility and malleability in addressing new needs of social inclusion. Take the case of Sweden, often held up as a shining example of social inclusion. Today the country is grappling with the challenges of immigration. Its institutions, which have historically responded positively to social and economic challenges, now need ways to accommodate a more heterogeneous population than Sweden has been used to. Institutions, in turn, are influenced by historical circumstance and can often be intractable to change as a result. 


\section{What Can Policies and Programs Do to Enhance Social Inclusion?}

$\bullet \bullet \bullet \bullet \bullet \bullet \bullet \bullet \bullet \bullet \bullet \bullet \bullet \bullet \bullet$

How do policies that are effective in addressing social exclusion differ from ordinary social policies? In essence, social inclusion policies are policies that do not necessarily do more but that do things differently. No single set of policies or programs can be classified as "social inclusion policies" or "social inclusion programs." In fact, depending on the "wrong" that needs to be addressed or the "right" that needs to be deepened, a range of interventions could be employed. This report provides a few examples of interventions within the broad typology of markets, services, and spaces, but any policy or program can be designed and implemented with a social inclusion focus.

Often the same policy or program can cut across different domainsmarket, services, and spaces. Policies toward social inclusion need to be connected or cross-sectoral. Social exclusion is a multidimensional process in which practices in one domain lead to or reinforce exclusion in another domain. Policies to address social exclusion therefore require what Silver (2013) calls "a dynamic sequence of interventions." Illustrating her argument with the case of the homeless, she argues that their inclusion in society requires a "continuum of care" starting from transitional housing, labor market training, and (possible) drug and alcohol treatment to (eventually) permanent housing, perhaps with long-term supportive services to help them stay housed. This report categorizes interventions into the domains of markets, services, and spaces, realizing that the domains overlap and that intervening in one domain can have effects in others.

Policies and programs can intervene in a range of markets. Take the case of land reforms. Although land reforms are not by themselves a panacea for exclusion or inequality, societies that have carried them out tend to be more inclusionary. Land titles to women and de facto recognition of the communal land use patterns of indigenous populations can be effective in creating opportunity and enhancing dignity. Women in many societies do not traditionally own land. Making them joint landholders in land redistribution or resettlement projects or reserving land use quotas can increase their access to opportunities while also empowering them. Deininger, Goyal, and Nagarajan (2010), for instance, find that coparcenary rights for women in property can have a positive effect on the education of girls within the household. Programs offering child care can enhance women's labor market outcomes. Both women's labor force participation rates and their wages are lower than men's, even after controlling for a range of individual and household level factors (World Bank 2012, 2013c). Many women cannot work because of their family responsibilities, yet child care in most places is costly and scarce. Programs providing subsidized child care not only can help women improve their labor market outcomes, they also can have other positive externalities as well.

Access to services that take into account the special needs of excluded groups can go a long way in enhancing social inclusion. Subsidized fares targeted to excluded groups and accessible transport services can help connect these groups to markets, services, and spaces. The city of São Paolo has chosen flat fares as an alternative to distance-based fares in order to cross-subsidize the poor. Fares are valid across multiple modes/trips on one journey. Some groups, such as women and people with disabilities, face additional barriers to using transport (for example, inadequate street lighting leading to concerns around safety, transport that is inaccessible to people with disabilities, and so forth). Here, too, countries are experimenting with innovative methods to address the challenges these groups face in physical mobility.

The manner in which services are provided matters almost as much as the technical design of the service. Stereotypes that are often ingrained in service providers can have a damaging effect on the way they treat their clients, but these issues are not insurmountable. A growing practice focuses on "cultural competencies" among service providers. This practice is particularly advanced in health and social 


\section{The Right Question}

Figure 7: How to Include: Addressing the High Numbers of Maternal Deaths among Tribal Women in India

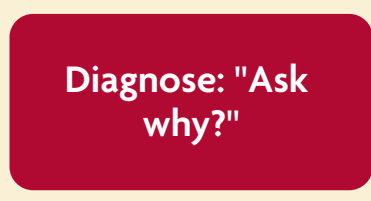

- Why do a large majority of tribal women say they don't think it's necessary to give birth in health facilities?

- If the reason is poverty, why are these women overrepresented among the poor?

- If the reason is lack of knowledge, why are they not better informed?

- If the reason is remoteness, why are they not connected?

Through:

- Conducting innovative ex ante analysis

- Holding meaningful consultations, including through the use of information and communications technology (ICT) to allow women to respond to questions anonymously

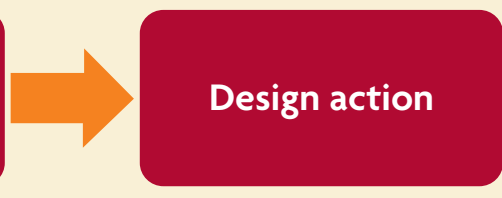

- Provide vouchers, grants, and culturally appropriate incentives

- Launch education/awareness campaigns in local language and idiom

- Register births and deaths

- Involve the community in health surveillance

- Use tribal systems of knowledge of health

- Establish links to other programs

- Make innovative use of private providers, including private transport agencies

- Hire more female staff from tribal communities

- Require cultural competency training for service providers

- Hold providers accountable for their behavior as well as technical skills

- Create incentives for providers to reside in remote areas

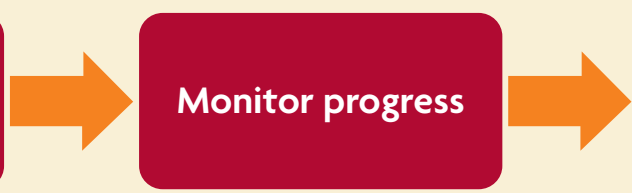

- Establish a monitoring framework that can be accessed by tribal people

- Create community monitoring mechanisms

- Establish third-party monitoring mechanisms

- Use social audits and hold public meetings

- Conduct "verbal autopsies"

- Mandate citizen report cards

- Publicly disclose results of monitoring, including through electronic channels

- Use ICT to solicit anonymous feedback
Create avenues for recourse and feedback

- Establish an empowered ombudsman-like institution that enforces tribal rights

- Empower tribal women through legislation and provide them with legal assistance

- Create independent help lines

- Establish local tribal health committees with access to district administration

- Form empowered grievance redress committees

- Establish systems to report back to communities on action taken
The report takes on one intractable problem - that of poor maternal health outcomes among indigenous groups-and argues that change toward social inclusion needs to start with the right diagnosis. It needs to "ask why" (figure 7).

Tribal women in India do not, for the most part, give birth in health centers. When they are asked why, the overwhelming majority of them say they do not think it necessary. Health practitioners then blame their poor health outcomes on low demand for formal health care. Continuing to ask why, however, reveals that low demand may reflect an assertion of dignity and a rejection of humiliation by excluded groups, in this case tribal women, who resent being treated badly by service providers.

Underlying the proximate reasons for poor outcomes are complex phenomena that are not immediately visible. Overall, the poor health of a tribal woman is rooted in the low power she has relative to almost everyone else in the country. Issues of land and forests are central to her situation. Once viewed in this way, it is clear that a supply-side push for better health facilities is a relatively blunt instrument with which to address high levels of maternal mortality.

Asking the right questions is likely to lead to a different design of a social program. Questions can include the following:

- What is the "wrong" or intractable problem being addressed, or what went "right" that needs to be deepened?

- Whom does the intervention or service seek to include, and who is at risk of being left out?

- Why are those groups or areas at risk of being left out? What are the channels through which inclusion can take place?

- What innovations can be put in place to ensure inclusion? What can be done differently? 


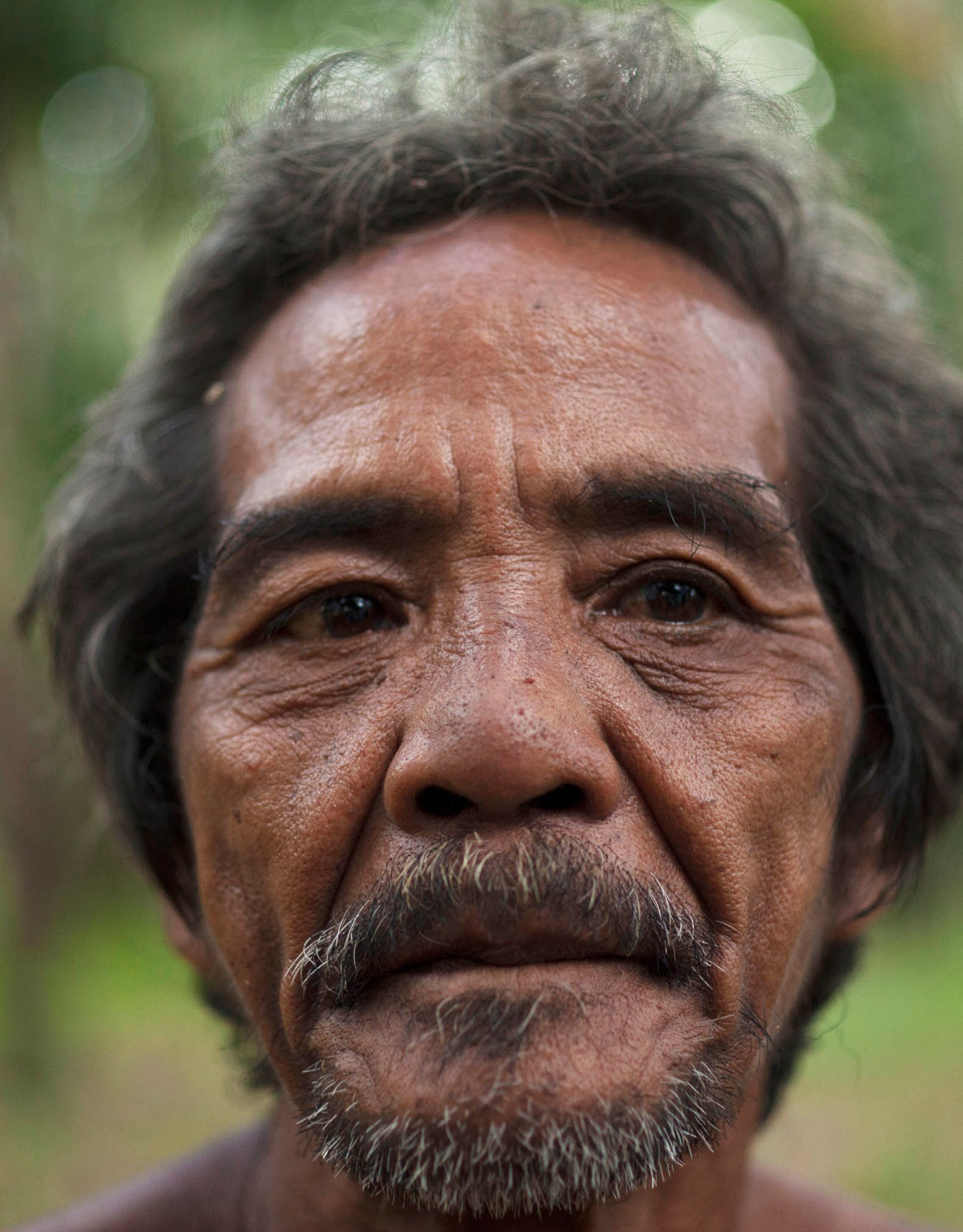




\section{Concluding Reflections}

Human progress is neither automatic nor inevitable. Even a superifial look at history reveals that no social advance rolls in on wheels of inevitability ... Without persistent effort, time itself becomes an ally of the insurgent and primitive forces of irrational emotionalism and social destruction. This is no time for apathy or complacency. This is a time for vigorous and positive action.
Although the contribution of this report to the world of ideas is an important objective, the report will be a larger public good only if it influences the world of research, policies, programs, and projects. What are the potential contributions of this report to the design and implementation of policies, programs, and projects? How does it highlight a new agenda for social inclusion?

It is hoped that this report speaks to practitioners in the following broad ways:

- It is an exhortation to both policy makers and researchers to use the term social inclusion with careful attention to meaning and boundaries.

- It brings some new ideas from philosophy and theory into the realm of practice.

- It highlights gaps in the understanding of social inclusion and potential areas for additional work through piloting new initiatives and undertaking new empirical analysis.

- It underscores the importance of additional work in measuring social inclusion.

- It emphasizes the importance of asking why poor outcomes continue to persist for some groups, before designing the instruments with which to combat exclusion.

- It stresses that building social inclusion is about building alliances and social consensus.

- It draws attention to the fact that monitoring change toward social inclusion needs innovation and that such innovation needs to be incorporated into practice.

- It is a call for greater participation of researchers to provide policy makers with the knowledge that will be essential for the wise design of social inclusion policies and programs. 


\section{References}

AAP (American Academy of Pediatrics). 2001. "The Continued Importance of Supplemental Security Income (SSI) for Children and Adolescents with Disabilities." Pediatrics 107 (4): 790-93.

AfDB (African Development Bank) Group. 2012. "Income Inequality in Africa." Briefing Note 5, AfDB, Tunis-Belvedère, Tunisia. http://www.afdb.org/fileadmin/uploads/afdb/Documents /Policy-Documents/FINAL\%20Briefing\%20Note\%205\%20 Income\%20Inequality\%20in\%20Africa.pdf (accessed April 5, 2013).

Barron, P., M. Humphreys, L. Paler, and J. Weinstein. 2009. "Community-Based Reintegration in Aceh: Assessing the Impacts of BRA-KDP.' Indonesian Social Development Paper 12, World Bank, Jakarta.

Beach, M. C., J. Sugarman, R. L. Johnson, J. J. Arbelaez, P. S. Duggan, and L. A. Cooper. 2005. “Do Patients Treated with Dignity Report Higher Satisfaction, Adherence, and Receipt of Preventive Care?" Annals of Family Medicine 3 (4): 331-38.

Bocian, D. G., W. Li, and K. S. Ernst. 2010. Foreclosures by Race and Ethnicity: The Demographics of a Crisis. CRL Research Report, Center for Responsible Lending, Durham, NC.

Borjas, G. J. 1992. "Ethnic Capital and Intergenerational Mobility." Quarterly Journal of Economics 107 (1): 123-50.

Carter, M. R. 2000. "Ownership Inequality and the Income Distribution Consequences of Economic Growth." Working Paper 201, United Nations University-World Institute for Development Economic Research (UNU-WIDER), Helsinki. http://www.wider.unu.edu /publications/working-papers/previous/en_GB/wp-201 /_files/82530864866142466/default/wp201.pdf.

Dadush, U. B., and W. Shaw. 2011. Juggernaut: How Emerging Markets Are Reshaping Globalization. Washington, DC: Carnegie Endowment for International Peace.
Das, M. B. 2008. "Minority Status and Labor Market Outcomes: Does India Have Minority Enclaves?" Policy Research Working Paper 4653, World Bank, Washington, DC.

2012. "Stubborn Inequalities, Subtle Processes: Exclusion and Discrimination in the Labor Market." Background paper for World Development Report 2013, World Bank, Washington, DC.

Deininger, K., and G. Feder. 1998. "Land Institutions and Land Markets." Policy Research Working Paper 2014, World Bank, Washington, DC. http://www-wds.worldbank.org/external /default/WDSContentServer/IW3P/IB/2000/02/24/0000949 46_99031911105637/Rendered/PDF/multi_page.pdf.

Deininger, K., A. Goyal, and H. Nagarajan. 2010. “Inheritance Law Reform and Women's Access to Capital: Evidence from India's Hindu Succession Act." Policy Research Working Paper 5338, World Bank, Washington, DC.

de Laat, Joost. 2010. "Roma Inclusion: An Economic Opportunity for Bulgaria, Czech Republic, Romania and Serbia." Policy Note, World Bank, Human Development Sector Unit, Washington, DC.

Demirgüç-Kunt, A., L. Klapper, and D. Randall. 2013. “The Global Findex Database. Financial Inclusion in Fragile and ConflictAffected States." Findex Note 07, World Bank, Washington, DC. http://siteresources.worldbank.org/EXTGLOBALFIN /Resources/8519638-1332259343991/N7fragileV5.pdf.

Deshpande, A., and K. Newman. 2007. "Where the Path Leads: The Role of Caste in Post-University Employment Expectations." Economic and Political Weekly 42 (41): 4133-40.

Elmslie, B., and S. Sedo. 1996. "Discrimination, Social Psychology, and Hysteresis in Labor Markets." Journal of Economic Psychology 17 (4): 465-78. 
Ferreira, F. H. G., J. Messina, J. Rigolini, L. López-Calva, M. A. Lugo, and R. Vakis. 2013. Economic Mobility and the Rise of the Latin American Middle Class. Washington, DC: World Bank.

Galbraith, J. K. 1998. The Affluent Society. New York: HoughtonMifflin.

Hall, G., and H. A. Patrinos, eds. 2006. Indigenous Peoples, Poverty, and Human Development in Latin America. New York: Palgrave Macmillan.

eds. 2012. Indigenous Peoples, Poverty, and Development. Cambridge, U.K.: Cambridge University Press.

Hersch, J. 2008. "Skin Color, Immigrant Wages, and Discrimination.” In Racism in the 21st Century: An Empirical Analysis of Skin Color, ed. R. E. Hall, 77-90. New York: Springer.

Jha, S., and M. Adelman. 2009. "Looking for Love in All the White Places: A Study of Skin Color Preferences on Indian Matrimonial and Mate-Seeking Websites." Studies in South Asian Film and Media 1: 65-83.

Kharas H., and G. Gertz. 2011. The New Global Middle Class: A Cross-Over from West to East. Brookings Institution, Wolfensohn Center for Development, Washington, DC. http://www.brookings. edu/ /media/Files/rc/papers/2010/03_china_middle_class _kharas/03_china_middle_class_kharas.pdf (accessed April 19, 2013).

Leibbrandt, M., I. Woolard, and C. Woolard. 2007. "Poverty and Inequality Dynamics in South Africa: Post-apartheid Developments in the Light of the Long-Run Legacy." Paper prepared for workshop sponsored by the International Poverty Centre and the David Rockefeller Center for Latin American Studies, Brasilia, January 11-13.

Loury, G. 1999. “Social Exclusion and Ethnic Groups: The Challenge to Economics." Paper presented at the Annual World Bank Conference on Development Economics, Washington, DC, April 28-30.

Lynch, D. 2012. “First Black President Can't Help Blacks Stem Wealth Drop." Bloomberg News, September 5.

Makours, K., and R. Vakis. 2009. “Changing Households' Investments and Aspirations through Social Interactions: Evidence from a Randomized Transfer Program." Policy Research Working Paper 5137, World Bank, Washington, DC.

Mansuri, G., and V. Rao. 2013. Localizing Development: Does Participation Work? Washington, DC: World Bank.

Marcus, R., S. Espinoza, L. Schmidt, and S. Sultan. 2013. "Social Exclusion in Africa: Towards More Inclusive Approaches." Background paper draft, World Bank, Washington, DC.
Minnesota Population Center. 2011. Integrated Public Use Microdata Series, International: Version 6.1 (machine-readable database). University of Minnesota, Minneapolis.

Muse, T. 2012. “New Drug Gang Wars Blow Colombian City's Revival Apart." Guardian, April 10. http://www.guardian .co.uk/world/2012/apr/10/colombia-drug-gang-rivalry-medellin (accessed May 16, 2013).

Ñopo, H., J. P. Atal, and N. Winder. 2010. "New Century, Old Disparities: Gender and Ethnic Wage Gaps in Latin America." IZA Discussion Paper 5085, Institute for the Study of Labor, Bonn.

Øyen, E. 1997. "The Contradictory Concepts of Social Exclusion and Social Inclusion." In Social Exclusion and Anti-poverty Policy: A Debate, ed. C. Gore and J. B. Figuereido, 63-66. Geneva: International Institute for Labour Studies.

Polanyi, K. 1944. The Great Transformation. Boston: Beacon Hill.

Portes, A., and L. Jensen. 1989. "The Enclave and the Entrants: Patterns of Ethnic Enterprise in Miami before and after Mariel." American Sociological Review 54 (6): 929-49.

Romero, S. 2007. "Medellin's Nonconformist Mayor Turns Blight to Beauty." New York Times, July 15. http://www .nytimes.com/2007/07/15/world/americas/15medellin .html?pagewanted=all\&_r=0 (accessed April 14, 2013).

Sen, A. 2000. “The Discipline of Cost-Benefit Analysis." Journal of Legal Studies 29 (S2): 931-52.

2001. Development as Freedom. Oxford, U.K.: Oxford University Press.

Shi, L. 2012. "Migration and Social Inclusion: Analysis of the WellBeing of Rural Migrants in China." Background paper draft, World Bank, Washington, DC.

Shonkoff, J. P., and S. J. Meisels. 2000. Handbook of Early Childhood Intervention, vol. 2. Cambridge, U.K.: Cambridge University Press.

Silver, H. n.d. "Social Exclusion.” In Encyclopedia of Sociology. Oxford, U.K.: Blackwell.

2013. “Framing Social Inclusion Policies." Background paper draft, World Bank, Washington, DC.

Tilly, C. 1999. Durable Inequality. Berkeley, CA: University of California Press.

Trujillo, M. D., and E. L. Paluck. 2012. “The Devil Knows Best: Experimental Effects of a Televised Soap Opera on Latino Attitudes toward Government and Support for the 2010 U.S. Census." Analyses of Social Issues and Public Policy 12 (1): 113-32. 
UBOS (Uganda Bureau of Statistics) and ICF International. 2012. Uganda Demographic and Health Survey 2011. Kampala, Uganda: UBOS; Calvert, MD, USA: ICF International.

UN (United Nations). 1993. World Economic Survey 1993. New York: United Nations.

2011. World Population Prospects: The 2010 Revision. New York: United Nations Secretariat, Department of Economic and Social Affairs, Population Division. ST/ESA/SER.A/313 (vol. 1) and ST/ESA/SER.A/317 (vol. 2). http://www.un.org/en /development/desa/publications/world-population-prospects -the-2010-revision.html.

. 2013. A New Global Partnership: Eradicate Poverty and Transform Economies through Sustainable Development. Report of the High-Level Panel of Eminent Persons on the Post-2015 Development Agenda. New York: United Nations. http://www .un.org/sg/management/pdf/HLP_P2015_Report.pdf.

Villarreal, M. A. 2010. "US-Mexico Economic Relations: Trends, Issues, and Implications." Library of Congress, Washington, DC.

Warschauer, M. 2003. Technology and Social Inclusion: Rethinking the Digital Divide. Cambridge, MA: MIT Press.

WDI (World Development Indicators) (database). World Bank, Washington, DC. http://data.worldbank.org/data-catalog/world -development-indicators.

Weeks, J. R., A. G. Hill, A. Getis, and D. Stow. 2006. "Ethnic Residential Patterns as Predictors of Intra-Urban Child Mortality Inequality in Accra, Ghana." Urban Geography 27 (6): 526-48.

WHO (World Health Organization) and World Bank. 2011. World Report on Disability. Geneva: World Health Organization. http:// www.refworld.org/docid/50854a322.html (accessed May 20, 2013).

Wilson, K. L., and A. Portes. 1980. “Immigrant Enclaves: An Analysis of the Labor Market Experiences of Cubans in Miami." American Journal of Sociology 86 (2): 295-319.
Wong, S. 2012. What Have Been the Impacts of World Bank CommunityDriven Development Programs? CDD Impact Evaluation Review and Operational \& Research Implications. World Bank, Sustainable Development Department, Washington, DC. http://www-wds .worldbank.org/external/default/WDSContentServer/WDSP /IB/2012/06/14/000386194_20120614062031/Rendered /PDF/695410WPOSWOCD00Box370017B00PUBLIC0.pdf.

World Bank. 2008. "Whispers to Voices: Gender and Social Transformation in Bangladesh." Bangladesh Development Series 22, World Bank, Dhaka.

2011a. Poverty and Social Exclusion in India. Washington, DC: World Bank.

2011b. "Social Safety Nets in Nepal." Draft report, World Bank, Washington, DC.

2012. World Development Report: Gender Equality and Development. Washington, Washington, DC: World Bank.

. 2013a. Turn Down the Heat: Why a $4{ }^{\circ} \mathrm{C}$ Warmer World Must Be Avoided. Report for the World Bank by the Potsdam Institute for Climate Impact Research and Climate Analytics. Washington, DC: World Bank.

_-_. 2013b. The World Bank Group Goals: End Extreme Poverty and Promote Shared Prosperity. Washington, DC. http:// www.worldbank.org/content/dam/Worldbank/document /WB-goals2013.pdf.

2013c. World Development Report: Jobs. Washington, Washington, DC: World Bank.

World Values Surveys (database). World Values Survey Association. http://www.worldvaluessurvey.org.

Yeo, R., and K. Moore. 2003. "Including Disabled People in Poverty Reduction Work: Nothing about Us, without Us." World Development 31 (3): 571-90. 

